\title{
Composition and Diversity of Soil Bacterial Communities along an Environmental Gradient in the Sudano-Sahelian Region of Senegal
}

\author{
Souleymane B. D. Diatta1,2, Laure N. Tall1,3, Yacine B. Ndour ${ }^{1,3}$, Mbacke Sembene'2, \\ Komi Assigbetsé1,4* (i) \\ ${ }^{1}$ LMI Intensification Ecologique des Sols cultivés en Afrique de l'Ouest (IESOL), IRD, Dakar, Senegal \\ ${ }^{2}$ Université Cheikh Anta Diop de Dakar, Département de Biologie Animale, Dakar, Senegal \\ ${ }^{3}$ Laboratoire National de Recherches sur les Productions Végétales (LNRPV), Institut Sénégalais des Recherches Agricoles, ISRA, \\ Dakar, Senegal \\ ${ }^{4}$ Eco \& Sols, Université de Montpellier, CIRAD, INRA, IRD, Montpellier SupAgro, Montpellier, France \\ Email: ${ }^{\star}$ Komi.Assigbetse@ird.fr
}

How to cite this paper: Diatta, S.B.D., Tall, L.N., Ndour, Y.B., Sembene, M. and Assigbetsé, K. (2020) Composition and Diversity of Soil Bacterial Communities along an Environmental Gradient in the Sudano-Sahelian Region of Senegal. Open Journal of Soil Science, 10, 58-89.

https://doi.org/10.4236/ojss.2020.102004

Received: January 30, 2020

Accepted: February 25, 2020

Published: February 28, 2020

Copyright $\odot 2020$ by author(s) and Scientific Research Publishing Inc. This work is licensed under the Creative Commons Attribution International License (CC BY 4.0).

http://creativecommons.org/licenses/by/4.0/

\begin{abstract}
The soils of the semi-arid Sudano-Sahelian region of West Africa have been identified as being highly vulnerable to soil degradation with impacts on their capacity to provide goods and services in which soil microorganisms participate. Unfortunately, soil microbial diversity from this semi-arid region with high rainfall variability remains largely unexplored. The aim of the present study was to characterize the diversity and composition of the soil bacterial communities and to identify factors involved in their spatial distribution along an environmental gradient in Senegal. Samples were collected from non-anthropogenic sites across four pedoclimatic zones. Bacterial communities were characterized using next-generation sequencing and soil physico-chemical parameters were determined. Our results showed that Firmicutes, Actinobacteria, Proteobacteria, Chloroflexi, Gemmatimonadetes, Acidobacteria, and Verrucomicrobia phyla were predominant in the soils of the region. Bacterial $\alpha$-diversity was stable along the environmental gradient whereas $\beta$-diversity highlighted significant changes in the composition of the soil bacterial community. Changes were driven by shifts in the relative abundance of OTUs belonging mainly to the genus Bacillus, Conexibacter, Kaistobacter, Solirubrobacter, Ktedonobacter, Sphingomonas, Microvirga, Rubrobacter and Pelobacter. Soil properties like $\mathrm{pH}$, soil moisture and clay content were the environmental parameters identified as drivers of the composition of the bacterial communities in the semi-arid Sudano-Sahelian region of Senegal (West Africa).
\end{abstract}




\section{Keywords}

Soil, Bacterial Diversity, Sudano-Sahelian, Pedoclimatic Gradient, Next-Generation Sequencing

\section{Introduction}

Soil microorganisms represent most biodiversity in terrestrial ecosystems [1]. As the most abundant groups of soil microbes and primary consumers in the soil food web [2], soil microorganisms such as bacteria and fungi play critical roles in regulating soil fertility, plant health, and soil nutrient cycling [3]. Despite their key role in soil biofunctioning that ensures many soil ecosystem services, studies on soil biodiversity are often overlooked [4], more so in drylands than in other ecosystems [5].

In semi-arid region, the Sudano-Sahelian zone (SSZ) of West Africa consists of two roughly parallel ecological regions, the Sahel and the Sudan [6]. The Sahel is located between the humid equatorial zone of Africa to the south and the Sahara desert to the north, within the semiarid to arid transition zone [7]. As one of the world's largest dryland areas [8], the Sahelian region has a very strong north-south gradient with between $200 \mathrm{~mm}$ and $600 \mathrm{~mm}$ annual rainfall [9] while the Sudanian zone receives between 600 and $1000 \mathrm{~mm}$ per year [10]. With its strong east-west uniformity of climate and vegetation conditions [9], the Sudano-Sahelian zone of West Africa (SSZ) presents diverse land covers. The northernmost areas of the Sahelian region are characterized by sparse vegetation and grassland interspersed with cropland while in the Sudanian zone in the south, shrublands, dense woody savannas and forest mosaics predominate [8] [11] [12]. The region is characterized by high rainfall variability [13]-[18] and has experimented severe and longest droughts during the twentieth century [19] [20] with persistent dry conditions since then [19]. In a context of climatic fluctuations and anthropogenic disturbances leading to land degradation in the region and where the impacts are most apparent in the surface vegetation cover [21], studies have mainly focused on the dynamics of vegetation and land cover changes [22]-[28]. While the relationship between vegetation and rainfall in these semi-arid environments has been extensively studied [5] [29], soil microbial communities remain largely unexplored.

Limited soil water availability (SWA) can impair the function of soil ecosystems long before symptoms become visible aboveground [30]. It is well known that a shift in the rainfall regime can directly affect soil microbial communities by altering soil water content, and indirectly by changing other physico-chemical features [31]. At regional scale, climate and soil parameters are usually identified as key predictors of microbial community structure [32]. Community structure and spatial variations in soil microbial communities have been documented at large spatial scales in different ecosystems and biomes 
ranging from polar [33] [34] to desert [35] [36] and including grasslands [37], steppes [38], forests [39], savannah [40]. Some soil properties and environmental variables such as precipitation [41], vegetation [42] [43], land use [44], $\mathrm{pH}$ [45], soil texture [46], carbon and nutrient content [47], soil moisture [48] have been described as potential driving factors of shifts in microbial communities [49].

An understanding of the factors that influence the biodiversity of soil bacterial communities is needed, first as a framework for determining the roles of different taxa in soils; and also to predict ecosystem responses to a changing environment [50]. In this work the objective was to explore in Senegal, a country partly straddling the Sudano-Sahelian zone (SSZ) of West Africa: 1) the composition and diversity of the soil bacterial communities and 2) to identify and prioritize among environmental parameters potential driving factors of the composition of bacterial communities in this semi-arid environment. Non-anthropogenic sites across four pedoclimatic zones forming an environmental gradient were sampled. We hypothesized that diversity and composition of the soil bacterial communities will vary along the environmental gradient, in response to climate and soil characteristics.

\section{Material and Methods}

\subsection{The Study Area Description}

The study was conducted in the Sahelian, Sahelo-sudanian and Sudanian climatic zones of Senegal $\left(12^{\circ} 30^{\prime}-16^{\circ} 30^{\prime} \mathrm{N} ; 11^{\circ} 30^{\prime}-17^{\circ} 30^{\prime} \mathrm{W}\right)$ a country located in the extreme western part of the African continent (Figure 1). Senegal has a semi-arid tropical climate with a cold dry season lasting from November to April and a hot rainy season from May to October. Soils range from dry sandy soils in the north to tropical ferruginous soils in the central region and to ferralitic highly leached soils in the south [51]. Rainfall distribution is characterized by an increase in the amount of precipitation and number of rainy days from the north to the south [52], resulting in a north-south spatial precipitation gradient. This pronounced climate gradient has led to the establishment of different climatic zones geographically defined on the basis of long-term precipitation averages, with a latitudinal pattern of vegetation types and ecosystems. Referring to [53] paper that provided ecological stratification of the Senegalese country in different ecoregions with overview of historical land use and land cover trends:

- The Sahelian climatic zone is a hot and dry semi-arid region that covers the northern part of the country. The climate is continental Sahelian with average annual rainfall below $400 \mathrm{~mm}$. The area includes the Senegal River Valley and a large sylvo-pastoral sandy area known as sandy "Ferlo" with ferruginous tropical soils and representing the Northern pastoral ecoregion. Vegetation is generally characterized by open herbaceous types (steppe and short grass savannah) often mixed with woody plants.

- The Sahelo-Sudanian climatic zone has acontinental Sahelian to Sahe- 
lo-Sudanian climate with average annual rainfall between 400 and $600 \mathrm{~mm}$. This climatic area includes mainly a West Central Agricultural Region with ferruginous tropical sandy soils slightly leached and pastoral areas formed at the West by the Southern Pastoral Region with sandy soils (Sandy "Ferlo") and at the East by the Ferruginous pastoral ecoregion (or Lateritic "Ferlo") with shallow, loamy, gravelly soils. Vegetation is characterized by shrubby savannah.

- The Sudanian climatic zone located in the southern half of the country present a coastal Sudanian climate in the west and continental Sudanian climate in the center and east. Average annual rainfall ranges from 600 to 800 $\mathrm{mm}$. The rainfall gradient is not north-south, which is the case at the two other sites but rather east to west. The Sudanian zone present two agricultural ecoregions at the West and an Eastern Transition Region with shallow loamy and gravelly soils over laterite on plateaus; sandy to loamy leached ferruginous soils in the valleys and terraces. The natural vegetation varied from degraded shrub and tree savannas to wooded savannah.

Details on the different ecoregions of the different climatic zones can be found in [53] paper.

\subsection{Soil Sampling Strategy}

Four sampling zones a priori different in climate and soil conditions were considered across the Sahelian, the Sahelo-sudanian and the Sudanian climatic zones (Figure 1). The first sampling area was located at the northern-west part of the Sahelian climatic zone. The second and the third sampling areas were located respectively at the northwestern part and the northeastern part of the Sahelo-sudanian climatic zone. The last and fourth sampling zone concerned the eastern part of the Sudanian climatic zone.

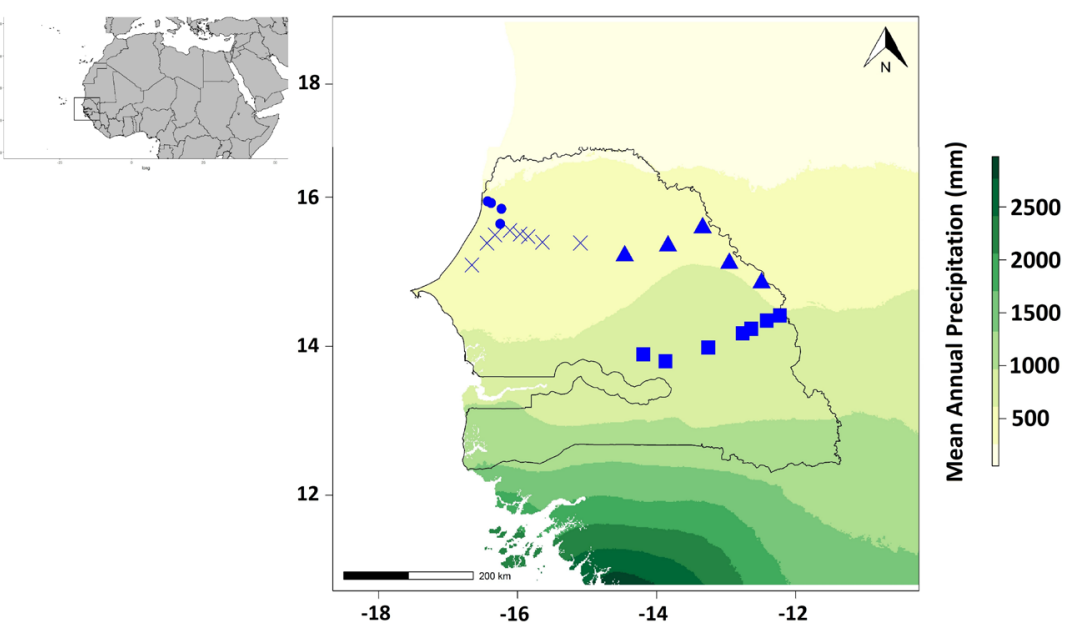

Figure 1. Map of the study area showing the location of the sampling sites across the sampling zone. Sahelian zone transect $(\bullet)$, Western Sahelo-Sudanian zone transect $(\times)$, Eastern Sahelo-Sudanian zone transect $(\bullet)$ and Sudanian zone transect $(\bullet)$. Average annual precipitation from the WorldClim 2 data collection [54]. 
Sampling was conducted at the end of the rainy season in November 2015. Using transect sampling strategy, soil samples were collected from random sampling sites along each sampling transect (national roads) with a total of 24 sampling sites. Samples were taken under similar vegetation cover (natural herbaceous cover) where no livestock grazed and no known human activities took place. In each sampling site or plot, one composite sample was collected from 5 core samples at $0-10 \mathrm{~cm}$ soil depth and $1 \mathrm{~m}$ apart, using a cylindrical soil sampler ( $5 \mathrm{~cm}$ inner diameter, $10 \mathrm{~cm}$ length). Composite samples were immediately placed in plastic bags and stored at $4^{\circ} \mathrm{C}$ in a cooler. Other soil cores were also collected for the determination of bulk density. Back to the laboratory coarse plant debris were removed prior to a gently air-drying and sieving at $2 \mathrm{~mm}$. Subsamples for molecular analyses were stored at $-80^{\circ} \mathrm{C}$ while subsamples for the determination of the physico-chemical analyses were air-dried and stored. Ecological characteristics and details of the sampling zones are summarized in Supplementary Table S1.

\subsection{Extraction of the Climate Data}

Mean Annual Temperature (MAT) and Mean Annual Precipitation (MAP) of each sampling site was extracted based on geographic coordinates (Latitude \& Longitude). Values extracted represented averages for the period (1970-2000) of bioclimatic variables of WorldClim 2 data collection [54] using BIO1 (Annual Mean Temperature) and BIO12 (Annual Precipitation) variables at a resolution of $1 \mathrm{~km}$ ( 30 arc-seconds).

\subsection{Soil Physical and Chemical Analyses}

Soil texture was determined by sedimentation using Robinson's technique [55]. Soil moisture content was calculated as follows: (mass of wet soil - mass of dry soil)/(mass of dry soil). Dry mass was determined from the mass of wet soil after drying at $105^{\circ} \mathrm{C} /$ for $48 \mathrm{~h}$ in an oven. Bulk density $\left(\mathrm{g} \cdot \mathrm{cm}^{-3}\right)$ was determined by the ratio (dry mass of volumetric sample)/(volume of the cylindrical soil sampler). Soil $\mathrm{pH}$ was quantified in a water soil suspension [soil: water ratio 1:2.5 (w/v)] (InoLab 720, WTW, Germany). Soil inorganic $\mathrm{N}\left(\mathrm{NH}_{4}^{+}-\mathrm{N}\right.$ and $\left.\mathrm{NO}_{3}^{-}-\mathrm{N}\right)$ was extracted from $10 \mathrm{~g}$ of fresh soil with $2 \mathrm{M} \mathrm{KCl}$ solution and measured using a colorimetric method with a flow injection auto-analyzer (SEAL analytical, Auto Analyzer 3-QuAAtro, Seal Analytical, France). Soil total nitrogen and carbon were quantified by combustion using ThermoFinnigan Flash EA 1112 (ThermoFinnigan, France). All these soils analyses were conducted at the Laboratoire des Moyens Analytiques (LAMA), a laboratory belonging to the Institut de Recherche pour le Développement (IRD) in Dakar, Senegal.

\subsection{DNA Extraction and 16S rRNA Gene Sequencing}

Total genomic DNA of each soil sample was extracted from $0.25 \mathrm{~g}$ of soil using the FastDNA ${ }^{\mathrm{m}}$ SPIN kit for Soil (MP Biomedicals, CA, USA) in accordance with 
the manufacturer's instructions. DNA extracts were purified by adding $500 \mu \mathrm{l}$ of guanidine thiocyanate $(5.5 \mathrm{M})$ and then centrifuged at $14000 \mathrm{~g}$ for $5 \mathrm{~min}$ at $4^{\circ} \mathrm{C}$. DNA was suspended in $150 \mu \mathrm{L}$ elution buffer and quantified with a NanoDrop ND-1000 spectrophotometer (NanoDrop Technologies, Wilmington, DE, USA) before being stored at $-20^{\circ} \mathrm{C}$ in the freezer. Sequencing of gene encoding $16 \mathrm{~S}$ rRNA was performed at MRDNA (http://www.mrdnalab.com/, Shallowater, TX, USA) with an Ion Torrent PGM system for sequencing (Life Technologies Corp., Thermo Fischer Scientific, Massachusetts, USA). Briefly, samples were barcoded and the V4 variable region of $16 \mathrm{~S}$ rRNA gene was targeted with the 515F/806R primer set [56]. PCR amplification was carried out using the HotStar Taq plus Master Mix Kit (Qiagen, Germantown, MD, USA) under the following conditions: one cycle at $94^{\circ} \mathrm{C}$ for $3 \mathrm{~min}$, followed by 28 cycles at $94^{\circ} \mathrm{C}$ for $30 \mathrm{~s}$, at $53^{\circ} \mathrm{C}$ for $40 \mathrm{~s}$ and at $72^{\circ} \mathrm{C}$ for $1 \mathrm{~min}$ plus a final elongation step at $72^{\circ} \mathrm{C}$ for $5 \mathrm{~min}$.

\subsection{Sequence Analysis Processing and OTU Clustering}

Barcodes and primers were removed from the sequences. Short sequences $<150$ bp, sequences with ambiguous base calls and sequences with homopolymer runs exceeding 6 base pairs were removed. The remaining sequences were then denoised and operational taxonomic units (OTU) were defined by clustering at $3 \%$ divergence (97\% similarity) followed by removal of singletons and chimeras. Final OTUs were taxonomically classified using BLASTn against a curated database derived from GreenGenes, RDPII and NCBI (http://www.ncbi.nlm.nih.gov/, [57], http://rdp.cme.msu.edu). Only OTUs identified up to at least the phylum level were kept on the final OTUs tables. The final OTUs tables containing the number of sequences per sample per OTU matching the designated taxonomic classification were then produced. The whole process was conducted at MR DNA using the MR DNA ribosomal and functional gene analysis pipeline (http://www.mrdnalab.com/, MR DNA, Shallowater, Texas, USA). The raw sequence reads were submitted to the NCBI SRA database under accession number PRJNA508511.

\subsection{Statistical Analysis}

\subsubsection{Analysis of Bacterial Diversity}

The analyses of the OTU tables were performed in R [58] using R phyloseq package [59]. OTU tables were first randomly subsampled according to the number of sequences obtained from the smallest library in order to deal with unequal sampling effort. We arbitrarily defined "Rare" and "Abundant" OTUs as follows: OTUs whose reads summed across all samples was less than $0.01 \%$ of the total number of bacterial sequences were defined as "rare taxa" while OTUS with total relative abundance greater than $0.01 \%$ were considered "abundant". Taxonomic composition and taxa relative abundances of the bacterial communities were determined by aggregating sequence counts of OTUs sharing the same taxon. Bacterial $\alpha$-diversity was evaluated for each soil sample by calculating richness and the Shannon and Simpson indexes using R Vegan software package 
[61]. One way analysis of variance (ANOVA) was used to compare $\alpha$-diversity between the pedoclimatic zones with XLSTAT software [60]. Changes in bacterial community composition ( $\beta$-diversity) between soil samples were assessed using a non-metric multidimensional scaling analysis (NMDS) based on the Bray-Curtis distance index calculated at the OTU level. NMDS ordination was then tested by PERMANOVA (distance-based permutational multivariable analysis of variance) using 9999 permutations with the Adonis function in the $\mathrm{R}$ Vegan package [61].

To identify the features (OTUs) that drive the structure of the bacterial community, sparse partial least square discriminant analysis (sPLS-DA) of abundant OTUs was conducted using the $\mathrm{R}$ mixOmics package [62]. sPLS-DA aims to identify a small subset of genes that best discriminate the groups according to a given factor by including a LASSO penalization to select the most informative predictors. Partial least squares discriminant analysis (PLS-DA) is an exploratory approach that seeks the optimal linear combinations of variables (genes) that best separate the sample groups [63]. The classification performance (classification error rate) of the model for the sPLS-DA were evaluated using the R perf function with a leave-one-out cross validation. Final predictors (OTUs) were grouped at the genus level to display taxonomic labeling.

\subsubsection{Relationship between Environmental Parameters}

Climate data and soil physical-chemical properties of the sampling zones were compared using Welch-ANOVA test with a significance level of 5\%. Games-Howell test were carried out to test for significant differences between treatments. The differences were considered significant at $\mathrm{P}<0.05$. Correlations between environmental variables were assessed by Pearson's test. All the statistical analyses were carried out using R XLSTAT software [60].

\subsubsection{Relationship between Bacterial Diversity and Environment Variables}

The relationship between bacterial diversity and environment variables was assessed by performing a distance-based redundancy analysis (db-RDA). The bacterial community composition matrix was generated from the OTU table using the Bray-Curtis dissimilarity index and the environmental data were first standardized by centering and scaling to avoid the effects of scale between the explanatory variables. The relative contribution of each significant explanatory variable to the fraction of variance explained by the environmental data was determined by analysis of variance (ANOVA)-like permutation test for canonical analyses (anova.cca function in the vegan package). All statistical analyses were performed on the R statistical platform using the vegan package [61].

\section{Results}

\subsection{Environmental Parameters}

Mean annual temperature (MAT) and Mean Annual Precipitation (MAP) varied 
significantly between the soil sampling zones (Table 1). MAT ranged from $25^{\circ} \mathrm{C}$ to $28^{\circ} \mathrm{C}$ while MAP ranged from 290.7 to $638.8 \mathrm{~mm}$. Soil textural classification revealed that the north-west Sahelian zone and the western Sahelo-Sudanian zone were characterized by sandy soils with more than $90 \%$ of sand. The eastern Sahelo-Sudanian and the Sudanian zones were more clayey (over 7\%) and silted (over 15\%) and comprised respectively loamy sand and sandy-loam soils (Table 1). As expected climate and soil texture characteristics differentiated our four sampling zones a priori different in soil and climate conditions in four pedoclimatic zones: a Sahelian sandy zone (SS), a Sahelo-Sudanian sandy zone (SSS), a Sahelo-Sudanian loamy-sand zone (SSLS) and a Sudanian sandy-loam zone (SSL).

Physico-chemical parameters varied in space with significant differences among the pedoclimatic zones (Table 2). Mean soil $\mathrm{pH}$ varied significantly between the soil samples and ranged from 5.72 to 7.43 across the sites. The SS soil samples were characterized by neutral $\mathrm{pH}$ while the others soil samples were slightly more acidic. Soil moisture, total $\mathrm{C}$, total $\mathrm{N}$ and mineral $\mathrm{N}$ contents were

Table 1. Climatic and textural characteristics of the sampling zones.

\begin{tabular}{cccccc}
\hline & $\begin{array}{c}\text { MAP } \\
(\mathrm{mm})\end{array}$ & $\begin{array}{c}\text { MAT } \\
\left({ }^{\circ} \mathrm{C}\right)\end{array}$ & $\begin{array}{c}\text { Sands } \\
(\%)\end{array}$ & $\begin{array}{c}\text { Clay } \\
(\%)\end{array}$ & $\begin{array}{c}\text { Silt } \\
(\%)\end{array}$ \\
\hline $\begin{array}{c}\text { Sahelian zone } \\
\text { Western }\end{array}$ & $290.8(23.6) \mathrm{a}$ & $25.8(0.5) \mathrm{a}$ & $94.7(1.3) \mathrm{a}$ & $2.2(0.3) \mathrm{a}$ & $3.2(1.3) \mathrm{a}$ \\
$\begin{array}{c}\text { sahelo-sudanian zone } \\
\text { Eastern }\end{array}$ & $377.1(19.8) \mathrm{b}$ & $27(1.1) \mathrm{ab}$ & $91.6(3.9) \mathrm{a}$ & $4.24(2) \mathrm{ab}$ & $4.2(2.1) \mathrm{a}$ \\
$\begin{array}{c}\text { sahelo-sudanian zone } \\
\text { Sudanian zone }\end{array}$ & $678.6(69.7) \mathrm{b}$ & $29.2(0.5) \mathrm{c}$ & $76.9(10.6) \mathrm{b}$ & $7.74(3) \mathrm{b}$ & $15.4(8) \mathrm{ab}$ \\
\hline
\end{tabular}

Values are means (Standard deviation). Values with different letter are significantly different $(\mathrm{P}<0.05)$.

Table 2. Soil physicochemical properties across the pedoclimatic zones.

\begin{tabular}{ccccc}
\hline \multirow{2}{*}{ Variables } & \multicolumn{4}{c}{ Pedoclimatic zones } \\
\cline { 2 - 5 } & Sahelian sandy & $\begin{array}{c}\text { Sahelo-sudanian } \\
\text { sandy }\end{array}$ & $\begin{array}{c}\text { Sahelo-sudanian } \\
\text { loamy sand }\end{array}$ & $\begin{array}{c}\text { Sudanian sandy } \\
\text { loam }\end{array}$ \\
\hline $\begin{array}{c}\text { Bulk density } \\
\left(\mathrm{g} / \mathrm{cm}^{3}\right)\end{array}$ & $1.8(0.02) \mathrm{a}$ & $1.8(0.1) \mathrm{a}$ & $1.8(0.1) \mathrm{a}$ & $1.9(0.1) \mathrm{a}$ \\
Soil moisture (\%) & $0.46(0.6) \mathrm{a}$ & $0.32(0.2) \mathrm{a}$ & $1.84(2.6) \mathrm{a}$ & $6.52(2.2) \mathrm{b}$ \\
$\mathrm{pH}$ & $7.4(0.6) \mathrm{a}$ & $6.3(0.5) \mathrm{b}$ & $6.1(0.4) \mathrm{b}$ & $5.7(0.5) \mathrm{c}$ \\
Total C (g/kg) & $0.8(0.3) \mathrm{a}$ & $0.7(0.3) \mathrm{a}$ & $1.1(0.6) \mathrm{a}$ & $2.2(0.7) \mathrm{b}$ \\
Total N (g/kg) & $0.05(0.06) \mathrm{a}$ & $0.06(0.05) \mathrm{ab}$ & $0.06(0.05) \mathrm{ab}$ & $0.14(0.05) \mathrm{b}$ \\
$\mathrm{N} \_\mathrm{min}(\mu \mathrm{g} / \mathrm{g})$ & $1.4(0.2) \mathrm{a}$ & $1.8(0.2) \mathrm{a}$ & $2.7(1.7) \mathrm{a}$ & $7.04(2.8) \mathrm{b}$ \\
$\mathrm{C} / \mathrm{N} \mathrm{ratio}$ & $15.8(1.9) \mathrm{a}$ & $14.6(7.7) \mathrm{a}$ & $36(17.9) \mathrm{a}$ & $16.8(2.2) \mathrm{a}$ \\
CEC (cmole/kg) & $1.9(0.3) \mathrm{a}$ & $1.8(0.7) \mathrm{a}$ & $3.3(2.5) \mathrm{a}$ & $2.7(0.9) \mathrm{a}$ \\
\hline
\end{tabular}

Values are means (Standard deviation). Values with different letter are significantly different $(\mathrm{P}<0.05)$. N_min $=$ Mineral nitrogen, $\mathrm{C} / \mathrm{N}=$ carbon/nitrogen ratio, $\mathrm{CEC}=$ Cation exchange capacity. 
significantly higher in the SSL soil samples than in the SS, SSS and SSLS samples (Table 2). Only soil bulk density, CEC and the $\mathrm{C} / \mathrm{N}$ ratio did not change significantly across the pedoclimatic zones. Pearson's correlation coefficient (Figure 2) revealed that MAT and MAP were both significantly correlated with clay and silt contents, total C, total N, mineral N, CEC and soil moisture, which in turn, also showed a positive correlation among them. In contrast, those soil properties were significantly negatively correlated with soil $\mathrm{pH}$, which in turn, was highly correlated with soil sand contents. Our results showed the study area to be clearly marked by a soil texture gradient consisting of an increase in clay, silt, total C, total N, mineral N, CEC and soil moisture contents and a decrease in $\mathrm{pH}$ and sand content from the Sahelian to the Sahelo-Sudanian zone and to the Sudanian zone.

\subsection{Taxonomic Composition of Soil Bacterial Communities}

Across the 24 soil samples, a total of 619,200 high-quality sequences were obtained and clustered in 17,253 bacterial OTUs. The majority of the OTUs i.e. $89 \%$ were present in low abundance while the abundant OTUs represented only $11 \%$ of the OTUs (Supplementary Table S2).

The taxonomic inventory of the bacterial sequences identified 24 phyla. The dominant bacterial phyla (Figure 3) were Firmicutes (30.42\%), Proteobacteria

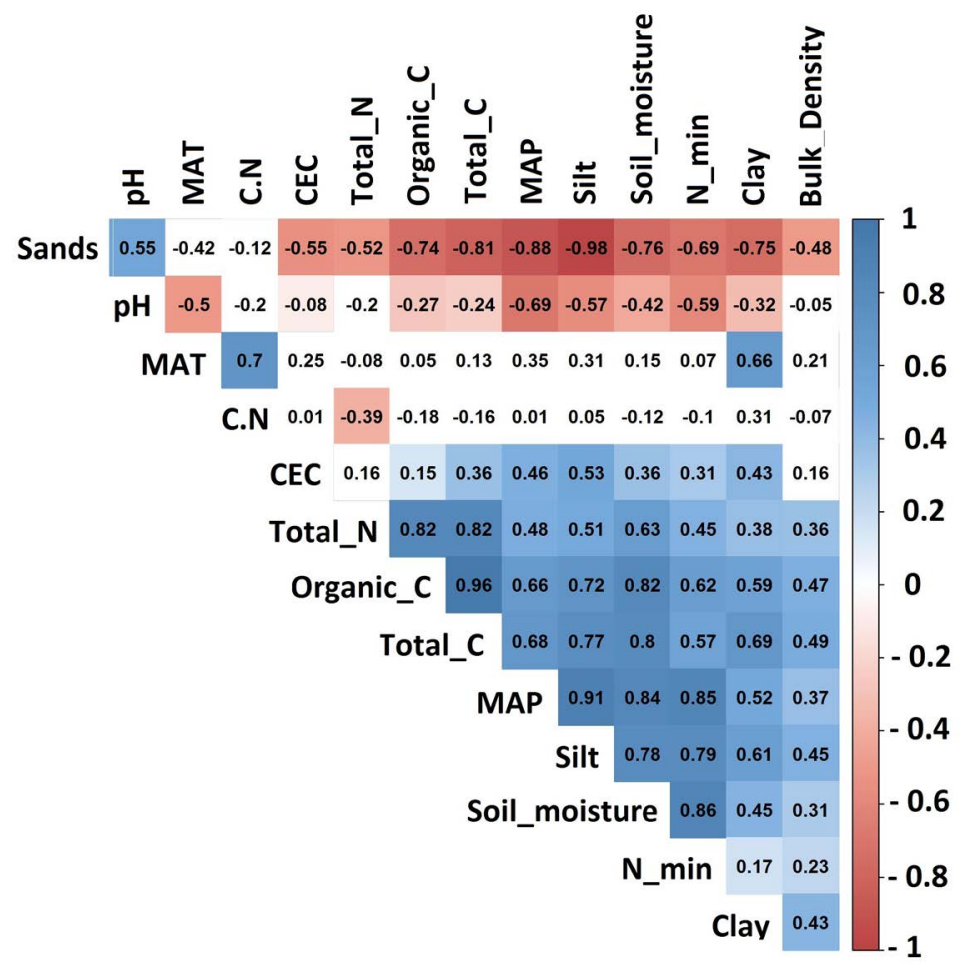

Figure 2. Pearson's correlations coefficients between the soil environmental (climatic and edaphic) variables. Positive significant relations are in blue and negative significant relations are in red, with the intensity of the relation changing from dark to light. 


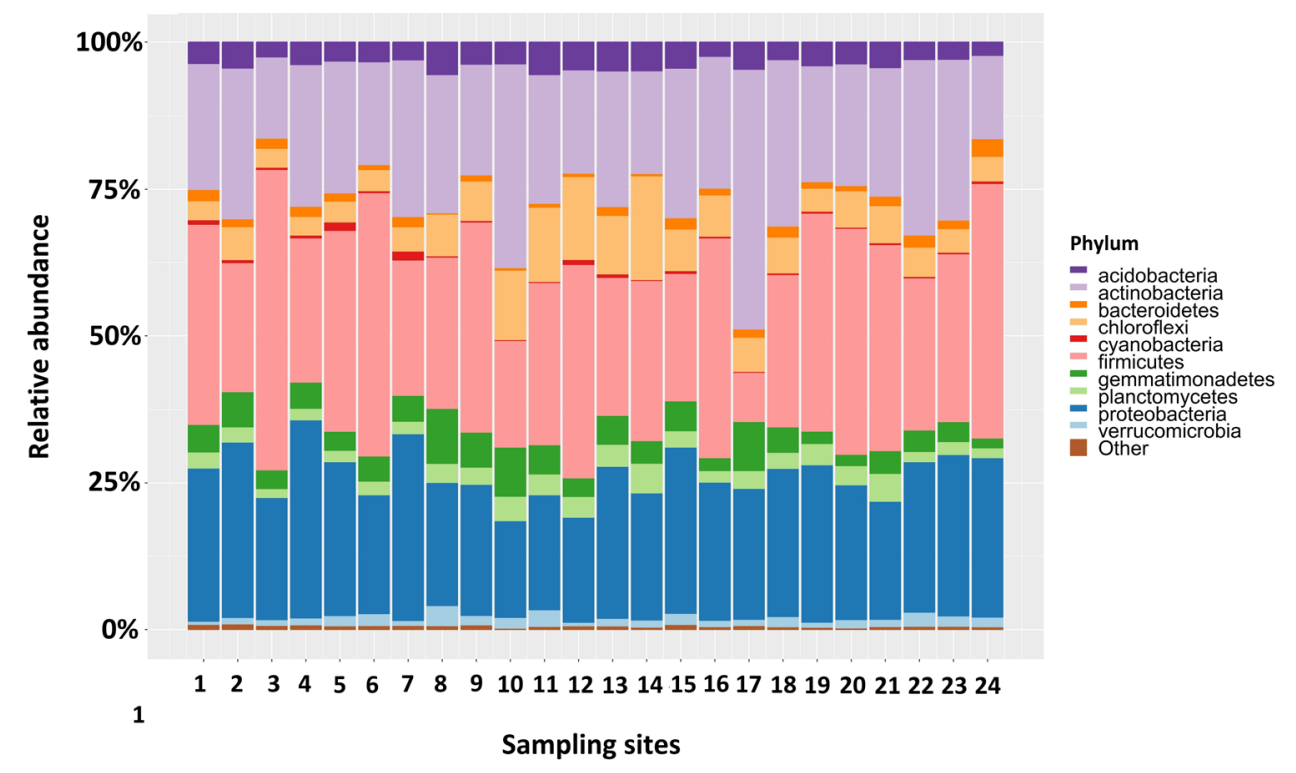

Figure 3. Taxonomic composition and relative abundance of the soil bacterial communities at the phylum level. Sites 1 to 4 = Sahelian sandy zone; Sites 5 to 13 = Sahelo-sudanian sandy zone; Sites 14 to 18 = Sahelo-sudanian loamy sand zone; Sites 19 to 25 = Sudanian sandy loam zone. Only top (relative bacterial abundance $>1 \%$ ) bacterial taxa are shown.

(24.33\%), Actinobacteria (23.44\%), Chloroflexi (6.77\%), Gemmatimonadetes (4.46\%), Acidobacteria (3.81\%), Planctomycetes (2.88\%), Verrucomicrobia (1.5\%), Bacteroidetes $(1.34 \%)$. These nine dominant phyla accounted for more than $98 \%$ of all the bacterial sequences. Rare phyla (relative bacterial abundance $<1 \%$ ) were represented by Cyanobacteria, Nitrospirae, Armatimonadetes, Deinococcus_thermus, Chlamydiae, Fibrobacteres, Fusobacteria, Ignavibacteriae, Synergistetes, Tenericutes, Elusimicrobia, Nitrospinae, Chrysiogenetes, Chlorobi and Thermodesulfobacteria.

At the class level, 50 bacterial classes belonging mainly to Firmicutes, Proteobacteria and Actinobacteria phyla were found across the samples. The most frequent were Bacilli (27.3\%), Actinobacteria (22.4\%), a-Proteobacteria (13.1\%), $\delta$-Proteobacteria (6.1\%), Gemmatimonadetes (4.5\%), $\beta$-Proteobacteria (3.5\%), Ktedonobacteria (3.2\%), Clostridia (3.1\%), Planctomycetia (2.6\%), Acidobacteriia (2.1\%), $\gamma$-Proteobacteria (1.7\%), Chloroflexia (1.6\%), Verrucomicrobiae (1.4\%) and Thermoleophilia (1\%) classes (Figure 4).

At low taxonomic level (genus level), 251 genera were detected. The most important (relative sequence abundance greater than 1\%) were Bacillus (17.4\%), Conexibacter (4.9\%), Ammoniphilus (3.4), Solirubrobacter (3.1\%), Microvirga (1.8\%), Rubrobacter (1.7\%), Streptomyces (1.6\%), Paenibacillus (1.5\%), Pelobacter (1.4\%), Sphingomonas (1.3\%), Bradyrhizobium (1.2\%), Gemmatimonas (1.1\%), Acidobacterium (1.1\%), Kaistobacter (1.0\%) (Figure 5). Proportion of bacterial sequences unidentified at genus level represented $24.5 \%$ of the total bacterial sequences.

Comparison of the composition of the bacterial communities at the different 


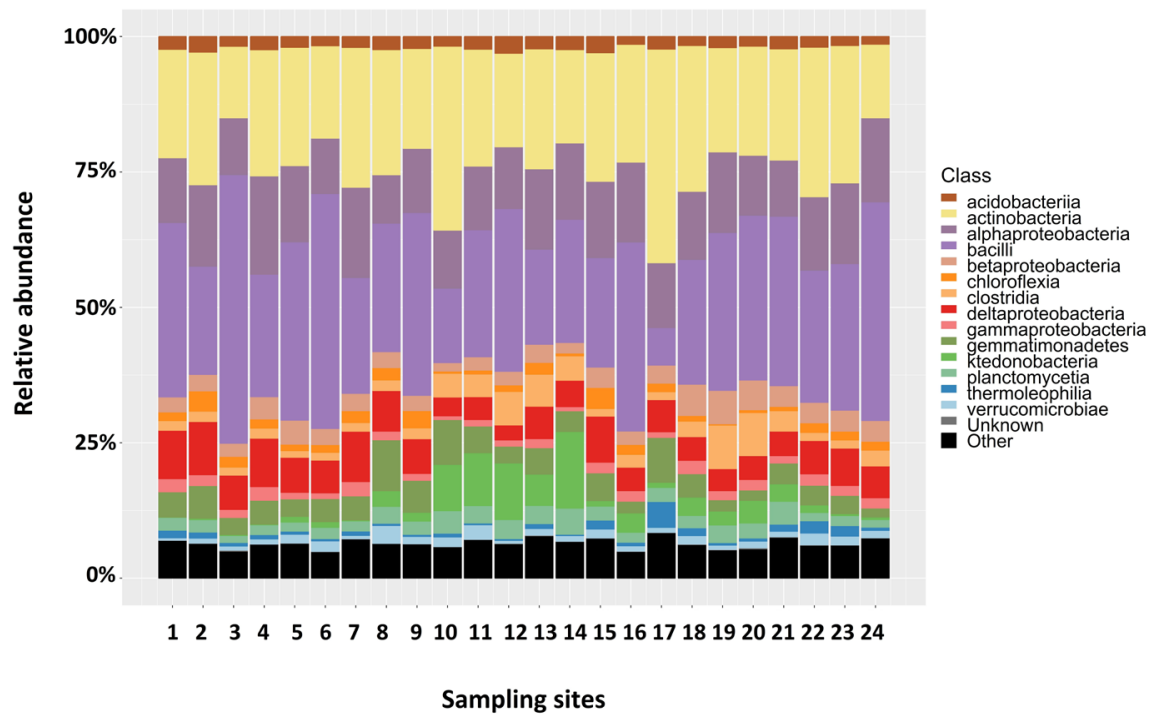

Figure 4. Taxonomic composition and relative abundance of the soil bacterial communities at the class level. Sites 1 to $4=$ Sahelian sandy zone; Sites 5 to $13=$ Sahelo-sudanian sandy zone; Sites 14 to 18 = Sahelo-sudanian loamy sand zone; Sites 19 to $25=$ Sudanian sandy loam zone. Only top (relative bacterial abundance $>1 \%$ ) bacterial taxa are shown.

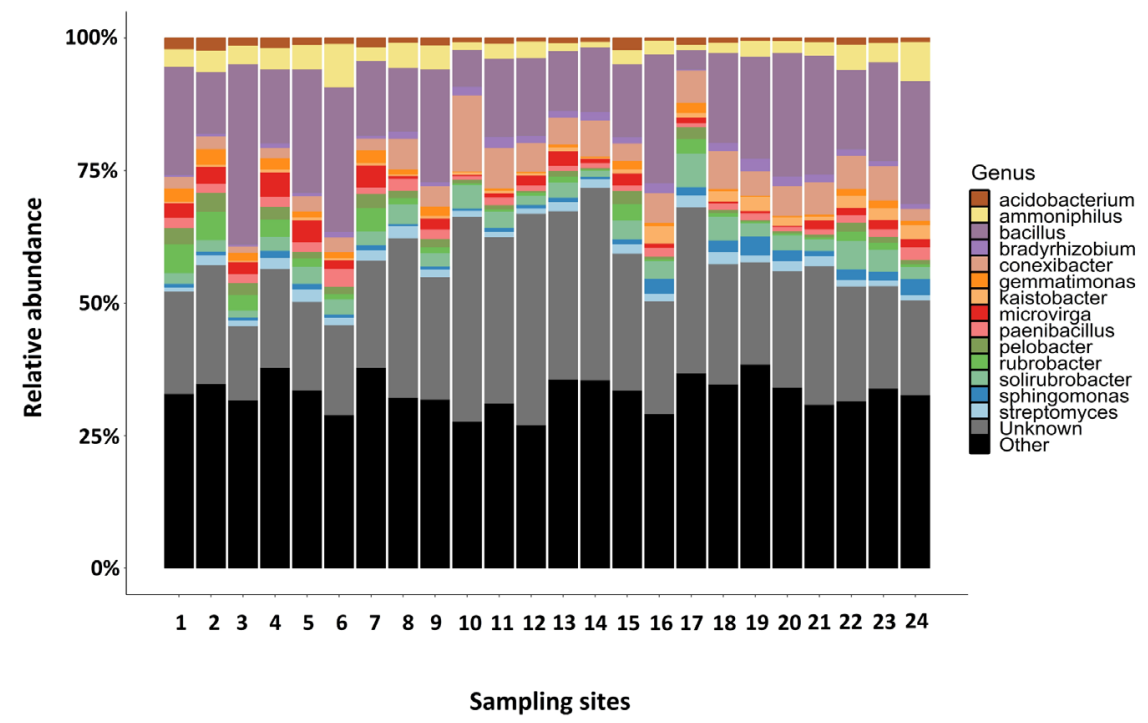

Figure 5. Taxonomic composition and relative abundance of the soil bacterial communities at the genus level. Sites 1 to $4=$ Sahelian sandy zone; Sites 5 to $13=$ Sahelo-sudanian sandy zone; Sites 14 to 18 = Sahelo-sudanian loamy sand zone; Sites 19 to $25=$ Sudanian sandy loam zone. Only top (relative bacterial abundance $>1 \%$ ) bacterial taxa are shown.

taxonomic level across the different pedoclimatic zones showed that the composition at low taxonomic level (genus level) was more spatially structured with clear distribution patterns of the relative abundance of some bacterial taxa, than at higher taxonomic level (phylum and class).

\subsection{Bacterial $\alpha$ and $\beta$-Diversity}

Our results showed that bacterial $\alpha$-diversity was stable across the different pe- 
doclimatic zones (Table 3). OTU richness was similar between the different pedoclimatic zones. The specific diversity based on the values of the Shannon and Simpson diversity indices, was high with codominance of species but like OTU richness did not vary significantly between the different pedoclimatic zones.

Changes in the bacterial community composition among the different groups of soil samples were assessed using NMDS ordination at the OTU level. Non-metric multi-dimensional scaling clustered the soil samples according to their pedoclimatic origin (Figure 6(a)). NMDS analyses without the rare OTUs did not alter the structuring patterns of the bacterial $\beta$-diversity (Figure $6(\mathrm{~b})$ ). Dissimilarities between soils groups seemed to be conserved across the two ordinations results (NMDS with and without the rare fraction). NMDS clustering was statistically supported by the PERMANOVA analysis (adonis $R 2=0.27, \mathrm{p}<$ 0.001 ) and confirmed that significant dissimilarities occurred in the composition of the bacterial communities.

\subsection{Predictors of the Structuring Patterns of Bacterial $\beta$-Diversity}

To identify OTUs involved in bacterial $\beta$-diversity structuring patterns, a

Table 3. Bacterial community richness and diversity indices across the pedoclimatic zones.

\begin{tabular}{cccc}
\hline Pedoclimatic zones & Richness & Shannon & Simpson \\
\hline Sahelian sandy & $4325(452) \mathrm{a}$ & $7.31(0.3) \mathrm{a}$ & $0.997 \mathrm{a}$ \\
Sahelo-sudanian sandy & $4182(457) \mathrm{a}$ & $7.24(0.2) \mathrm{a}$ & $0.996 \mathrm{a}$ \\
Sahelo-sudanian loamy sand & $4172(456) \mathrm{a}$ & $7.32(0.3) \mathrm{a}$ & $0.997 \mathrm{a}$ \\
Sudaniansandy loam & $4264(204) \mathrm{a}$ & $7.21(0.2) \mathrm{a}$ & $0.996 \mathrm{a}$ \\
\hline
\end{tabular}

Values are means (Standard deviation). Values with different letter are significantly different $(\mathrm{P}<0.05)$.

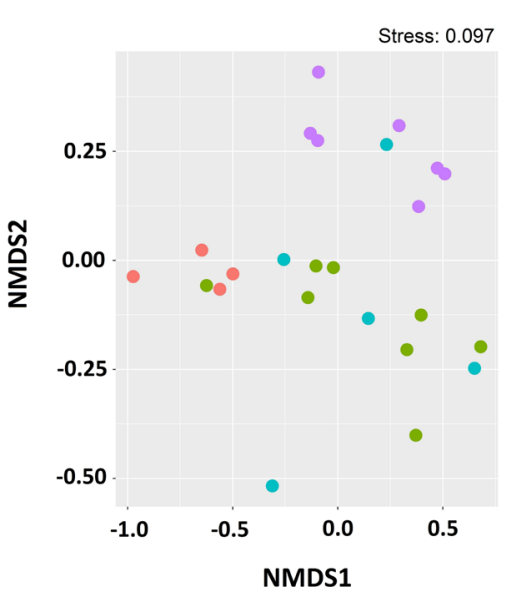

(a)

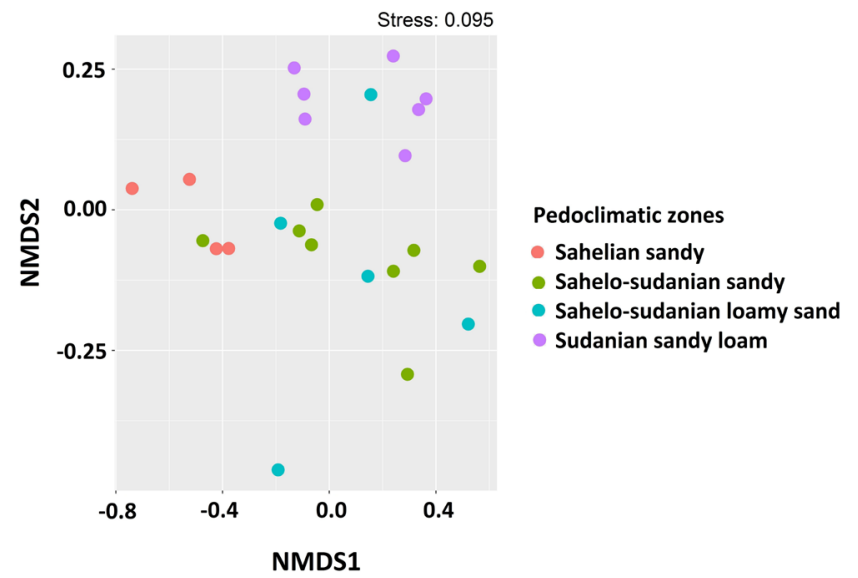

(b)

Figure 6. NMDS ordination of the soils bacterial communities. (a) The rare fraction community was included in the analysis. (b) The rare fraction community was excluded from the analysis. Each point represents a soil sample community: Sahelian sandy zone (Red circles); Sahelo-sudanian sandy zone (Green circles); Sahelo-sudanian loamy sand zone (Green circles), Sudanian sandy loam zone (Purple circles). 
sPLS-DA analysis was performed on the abundant fraction of the bacterial community at the OTU level. The sPLS-DA analysis distinguished the soil samples according to their pedoclimatic origin (Figure 7(a), Figure 7(b)), confirming the significant changes in the bacterial community composition between the soil groups. The four (4) pedoclimatic zones defined in the study were clearly separated by the first three PLS components with respectively $23 \%, 12 \%$ and $6 \%$ of the variance. Numerous unique OTUs ( 1,311 OTUs) were identified as drivers of the clustering of the soil samples across the three components of the sPLS-DA.

The first sPLS-DA component with a selection of 429 OTUs mainly separated the Sahelian sandy zone (SS) from soils of other areas and more particularly those from the Sudanian sandy-loam zone (SSL). OTUs characterizing the Sahelian sandy zone (SS) were predominantly assigned to the genus Bacillus, Rubrobacter, Microvirga, Pelobacter, Ammoniphilus, while Solirubrobacter, Conexibacter, Kaistobacter, Bacillus and Sphingomonas were mainly associated with the Sudanian sandy-loam zone (SSL).

The second sPLS-DA component with 419 discriminating OTUs separated the soils of the sandy Sahelo-Sudanian zone (SSS) but also those of the Sudanian sandy-loam zone (SSL) from the soils of the others pedoclimatic zones. The OTUs characterizing the sandy Sahelo-Sudanian zone (SSS) were mainly affiliated to the genera Conexibacter and Bacillus while those (160 OTUs) characterizing the Sudanian sandy-loam zone (SSL) belonged to the genera Kaistobacter, Sphingomonas, Bacillus and Conexibacter. The third and last sPLS-DA component, with a selection of 703 OTUs, separated the soils of the Sahelo-Sudanian loamy-sand zone (SSLS) from the others soil groups. The OTUs characterizing this pedoclimatic zone belonged mainly to the genus Conexibacter and Solirubrobacter. All the predictors OTUs characterizing each pedoclimatic zone were displayed on a heatmap (Figure $7(\mathrm{c})$ ) highlighting changes that occurred in the composition of the soil bacterial communities across the four pedoclimatic zones.

The results of the sPLS-DA analysis clearly showed that the structuring patterns of the bacterial $\beta$-diversity across the pedoclimatic zones were driven by shifts in the relative abundance of OTUs belonging mainly to the genera Bacillus, Rubrobacter, Microvirga, Pelobacter, Solirubrobacter, Conexibacter, Kaistobacter and Sphingomonas. Assessment of the spatial distribution of the abundance of the said genera across the pedoclimatic zones confirmed the distribution patterns previously mentioned. Conexibacter and Solirubrobacter genus belonging to the Actinobacteria class showed increasing abundances from the dry Sahelian sandy zone (SS) to the more humid Sudanian sandy-loam zone (SSL) whereas the abundance of Rubrobacter genus belonging also to Actinobacteria decreased (Supplementary Figure S1). Similarly, Kaistobacter and Sphingomonas belonging to the $\alpha$-proteobacteria class showed increasing abundances from the dry Sahelian sandy zone (SS) to the more humid Sudanian sandy-loam zone (SSL) while Microvirga also affiliated to $\alpha$-proteobacteria showed the 


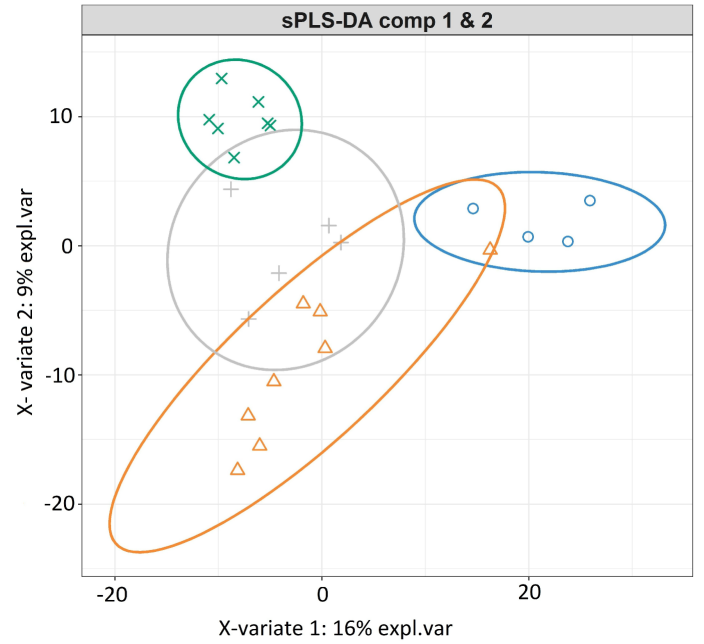

(a)

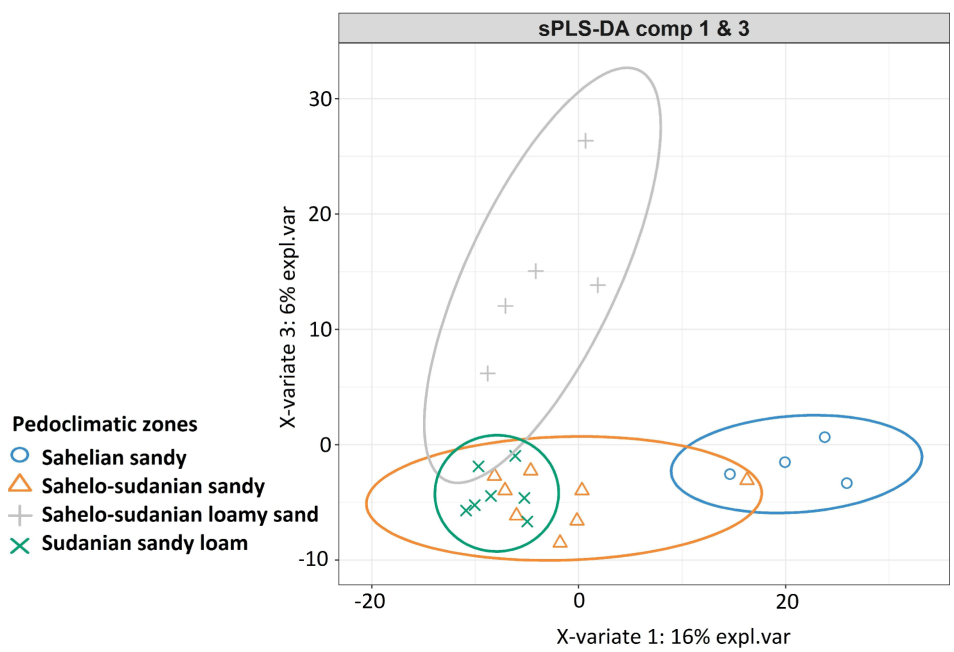

(b)

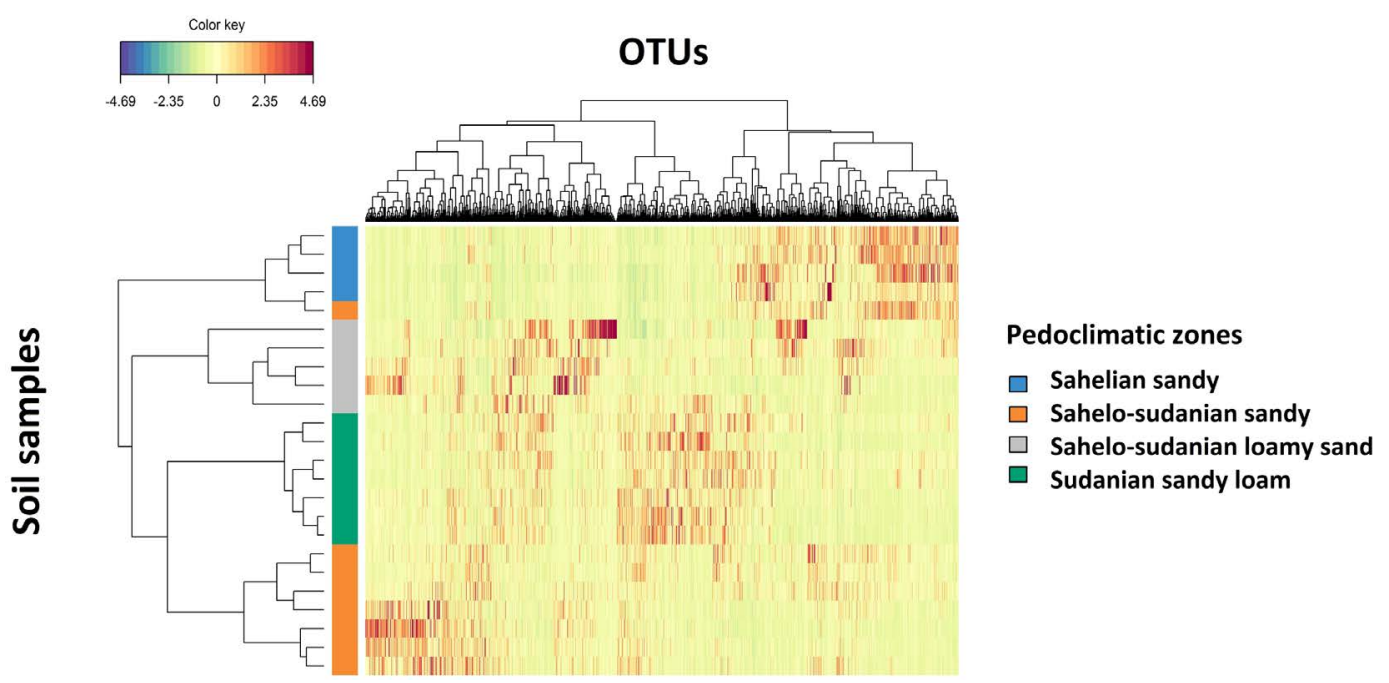

(c)

Figure 7. sPLS-DA score plot distinguishing soil bacterial communities according to the pedoclimatic zone on the first (a) and second component (b) of the sPLS-DA analysis. (c) Clustered Image Map (CIM) of the OTUs selected on the three components of the sPLS-DA: the heatmap highlights the OTUs that best characterize the different soils groups (pedoclimatic zones). Soil samples clusters are indicated on the left-hand side of the heatmap and OTUs clusters on the top.

opposite trend (Supplementary Figure S2). Pelobacter genus affiliated to $\delta$-proteobacteria class rather showed decreasing abundance from the dry Sahelian sandy zone to the Sudanian sandy-loam zone (SSL) (Supplementary Figure S3).

Finally, genus Bacillus did not show spatial variation; the genus predominated in all soils regardless of their pedoclimatic origin (Supplementary Figure S5).

Additionally, these results indicated that these genera driving the structuring patterns of the bacterial $\beta$-diversity along the pedoclimatic gradient belonged mainly to Bacilli, $\alpha$-Proteobacteria, $\delta$-Proteobacteria, Ktedonobacteria and Actinobacteria classes with some bacterial genera belonging to the same phylum but with divergent distribution patterns of their relative abundance. 


\subsection{Relations between Bacterial Community Composition and Environmental Variables along the Climatic Gradient}

Distance-based redundancy analysis (db-RDA) was used to determine the influence of environmental variables on bacterial community composition along the pedoclimatic gradient. Soil $\mathrm{pH}$, moisture and clay content were the only environmental parameters that were significantly correlated with the bacterial $\beta$-diversity patterns (Supplementary Table S3). These three variables explained $25.5 \%$ of the dissimilarities between the bacterial communities with the soil $\mathrm{pH}$ as the main driver, followed by soil moisture and then by soil clay content.

The db-RDA plot (Figure 8) displayed these significant relations. The first $\mathrm{db}-\mathrm{RDA}$ axis related to soil $\mathrm{pH}$, showed clearly a structured pattern of the bacterial communities. Bacterial communities from the Sahelian sandy soils, characterized by neutral $\mathrm{pH}$, were separated from bacterial communities of the others pedoclimatic zones characterized by more acidic $\mathrm{pH}$ values. The second $\mathrm{db}-\mathrm{RDA}$ axis correlated with soil moisture and soil clay contents formed two clusters separating the bacterial communities of the sandy Sahelian and Sahelo-Sudanian zones from those of the Sahelo-Sudanian loamy-sand zone (SSLS) and Sudanian sandy-loam zone (SSL).

\section{Discussion}

\subsection{Taxonomic Composition of the Soil Bacterial Communities}

Taxonomic composition of soil bacterial communities of the Sudano-sahelian region of Senegal revealed the predominance of Firmicutes, Chloroflexi and Gemmatimonadetes besides Acidobacteria, Proteobacteria and Actinobacteria phyla generally considered as the most abundant in soils [45] [64]. This finding agrees with those of the rare studies on microbial communities conducted in

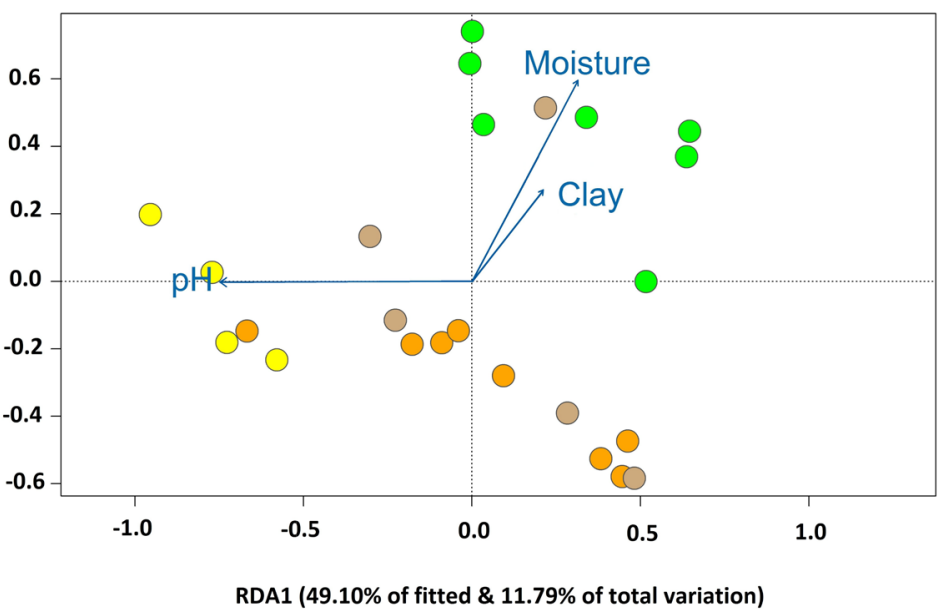

Pedoclimatic zones

Sahelian sandy Sahelo-sudanian sandy Sahelo-sudanian loamy sand Sudanian sandy loam

Figure 8. Distance based redundancy analysis (db-RDA) showing relations between bacterial community structure and explanatory variables. Each point represents a soil sample community: Sahelian sandy zone (Yellow circles); Sahelo-sudanian sandy zone (Orange circles); Sahelo-sudanian loamy sand zone (Brown circles), Sudanian sandy loam zone (Green circles). 
tropical Africa. In nutrient-poor sandy savannah soils in South Africa, Rughöft et al. [40] found a bacterial community dominated by Actinobacteria, Chloroflexi and Firmicutes members, except for Proteobacteria which were absent whereas they were well represented in our soils. In the sand dunes and inter-dune zones of the hyper-arid central Namib Desert, Ronca et al. [65] reported a similar bacterial community composition with seven phyla whose relative abundances were greater than $1 \%$ including Proteobacteria, Actinobacteria, Firmicutes and Chloroflexi members. The composition of the bacterial communities found in our study as regards the predominant phyla was clearly different to the composition of the bacterial community usually observed in temperate ecosystems and relatively similar to the composition of soil bacterial communities observed in soils from arid and semi-arid environments in several contexts like desert [35] [36], a land subsidence zone [66], an agroecosystem [67] [68], and an experimental precipitation gradient [69].

Senegal straddles the Sahel and experienced long drought events in the 1970s and 1980s [70] [71] with a dramatic decline in rainfall [72] and persistent dry conditions since then [19]. The climate of the region is also characterized by marked seasonality with a short rainy season in boreal summer, less rain in the winter season and high inter-annual variability [73]. Frequent extreme drying-rewetting events may select for microbial taxa that are more tolerant to desiccation stress, and these changes may result in a community that responds differently to moisture stress [74]. In a desiccation and rewetting experiment on Mediterranean grassland soils, Barnard et al. [75] pointed out that Proteobacteria, Chloroflexi, Firmicutes, Gemmatimonadetes and Planctomycetes members displayed stable and resistant life-strategies to response to environmental conditions.

Evans et al. [74] showed in soils exposed to frequent drying rewetting stress a bacterial community dominated by a greater proportion of stress tolerant taxa while in soils exposed to Ambient precipitation regime pulse- or drought-sensitive organisms predominate. Arid climates drive the assemblage of a community less sensitive to limited precipitation and adapted to desiccation stress by promoting the occurrence of more oligotrophic bacteria [38] [75]. According to Makhalanyane et al. [76] some Firmicutes spp. can form endospores that facilitate survival underdesiccating conditions. Members of Chloroflexi, Gemmatimonadetes and Verrucomicrobia that are considered to be less abundant in soils [64] have frequently been found in many dryland ecosystems while Gemmatimonadetes are known to be particularly adapted to low-moisture environments [77]. In our study, Acidobacteria and Bacteroidetes were present at relatively low abundance. Poor nutrient contents of our soils may explain the low relative abundance of Bacteroidetes members known to be copiotrophs [78] while the soil $\mathrm{pH}$ of our soils close to neutral might have impacted Acidobacteria members well adapted to low carbon availability [78] and known to increase in relative abundance when soil pH declines [45] [79]. 


\subsection{Bacterial $\alpha$ and $\beta$-Diversity}

Composition of the soil bacterial communities across the four pedoclimatic zones along the precipitation gradient revealed significant dissimilarities as shown by the Non-metric multi-dimensional scaling clustering of the soil samples according to their pedoclimatic origin (Figure 6(a)). Previous studies have shown that a change in environmental conditions, including rainfall gradient, can affect the composition of the community of soil bacteria [38] [48] [80] [81]. Structuring patterns of the bacterial $\beta$-diversity along the pedoclimatic gradient were predicted by shifts in the distribution of some OTUs mainly belonging to Bacillus, Rubrobacter, Pelobacter, Microvirga, Ktedonobacter, Conexibacter, Kaistobacter, Solirubrobacter, and Sphingomonas genera. Among the most abundant, these bacterial taxa showed spatial variations of their abundance along the gradient of environmental conditions (Supplementary Figures S1-S5) with divergent distribution patterns across the pedoclimatic zones even for taxa belonging to the same class or phylum. As Evans et al. [82] explain, climate-driven shifts in community composition could be due to the ecological traits of certain taxa that increase their ability to thrive under a particular climate regime. Bacterial assemblages exhibited vast physiological diversity at high taxonomical levels (class or phylum) and therefore spatial patterns of bacteria are more noticeable at low taxonomical levels (strain or species) because in this case ecological traits are common to the most members of the selected operational unit with consequently similar responses to environmental gradients [83]. Also, as said by Makhalanyane et al. [76], not all members of a given phylum are necessarily in the same ecological category and given the diversity present in some bacterial phyla, it is unlikely that an entire phylum shares the same ecological characteristics [78] [84]. These divergent responses probably contributed to make less perceptible changes in the community composition at higher taxonomic ranks like phylum or class. The exploration of changes in the community composition was more relevant at low taxonomic level. However, it is difficult to draw robust conclusions about the ecological properties of soil bacteria at that low level because well-characterized groups of bacteria generally concerned high taxonomic ranks such as phylum and class.

While bacterial community composition varied among the pedoclimatic zones, $\alpha$-diversity did not vary across the pedoclimatic gradient (Table 3 ). It remained stable across the different pedoclimatic zones with a common pattern of diversity characterized by predominant taxa in the same proportions versus a lot of minority taxa. These findings underline the presence of dominant species along the gradient and confirm the observed opposing shifts in the relative abundance of some bacterial taxa that certainly contributed to the stability of the bacterial $\alpha$-diversity across the pedoclimatic zones. Changes in microbial community structure do not necessarily lead to altered diversities, because changes in some taxonomic groups may be offset by changes in others [85]. Similar stability of the bacterial $\alpha$-diversity in different soil water conditions has also been 
found in many other studies conducted in arid and semi-arid areas [48] [86]. Along a precipitation and temperature gradient in Eastern Inner Mongolia, Yaoet al. [38] found no significant differences in the observed species and bacterial $\alpha$-diversity indices along a gradient of increased precipitation.

\subsection{Relations between Bacterial Diversity and Environmental Parameters along the Rainfall Gradient}

It is well known that environmental factors, including climate, soil type, soil properties and geographic location can affect soil microbial communities [66]. Soil $\mathrm{pH}$, soil moisture and soil clay content were significantly correlated with changes in the bacterial community composition in our study (Figure 8). Influence of parameters for which we have observed a significant spatial variation along the pedoclimatic gradient suggest to a certain extent involvement of deterministic processes in the composition of soil bacterial communities.

Our study, like other studies in various ecosystems like cold desert [33] [87], lake sediments [88], a continental environmental gradient [45] [89], an elevation gradient [90], forests [91], deserts [92], wetlands [93], land use [67] [68] [94], and arable soil [95], reveals that $\mathrm{pH}$ is one of the most important driver of bacterial community diversity and composition. The db-RDA plot (Figure 8) clearly displayed this influence of soil $\mathrm{pH}$, by allowing the separation of soils with a $\mathrm{pH}$ close to the neutrality from soils with a slightly more acidic $\mathrm{pH}$. Like soil $\mathrm{pH}$, spatial variations of soil moisture, result mainly from natural gradients or global climate change [48] and highly dependent on precipitation patterns [96], have significantly impacted bacterial $\beta$-diversity. Changes in microbial community composition and shifts in soil moisture due to variation in precipitation have been already report by some studies [39] [48]. Variation in soil moisture has a direct effect on bacterial communities due to the physiological stress experienced by these microorganisms, but also an indirect effect by regulating the availability of nutrients, which selects the best adapted bacteria to the soil conditions [47]. In this semi-arid region, soil moisture appeared also as for aboveground ecosystems, a strong predictor of belowground communities like soil microorganisms.

Soil clay content was the last significant factor correlated with changes in the composition of the bacterial community in our study. Soils of the region are characterized by a large mineral fraction, predominantly sandy with low levels of organic matter [97] [98], so soil clay content represents undoubtedly an important factor, determining soil texture and consequently soil moisture and nutrient contents. Soil clay content was positively correlated with soil moisture and soil nutrient content (Figure 2). In a study in the "Ferlo" region in Senegal, Fayeet al. [99] found a strong correlation between the soil moisture index and the nature of the geological formations, and stated that the variability of soil moisture was related to soil characteristics. Soil texture is important in determining soil moisture and nutrient status, which may have a significant impact on bacterial communities [100]. Xue et al. [49] determined that the effects of clay content and soil moisture content were considerable in controlling soil microbe variation 
along a climatic gradient. Hemkemeyer et al. [101] reported that bacteria can exhibit distinct preferences for a particular soil particle size fraction probably contributing to the spatial heterogeneity and bacterial diversity found in soils.

Soil $\mathrm{pH}$, moisture content, and plant-derived organic carbon inputs are major factors known to shape the composition of soil microbial communities [3]. In our study, only soil $\mathrm{pH}$ and moisture content shaped the structure of the soil bacterial communities. This lack of organic matter impact may be due to the low level of organic matter that characterizes all the soil samples in a region where soils are known to be nutrient-poor. Soils are physically, chemically, and biologically heterogeneous, providing a wide range of niches to maintain microbial diversity [102]. Further studies on a variety of soils and environments are needed to obtain a more comprehensive picture of microbial community diversity and structure [103] in the semi-arid Sahelo-Sudanian region of Senegal.

\section{Conclusion}

The objective of this study was to explore in the Sudano-sahelian region of Senegal, the diversity and composition of soil bacterial communities along a pedoclimatic gradient and to improve our knowledge of the environmental factors that drive the spatial distribution of soil the bacterial community. Our study showed that the composition of the soil bacterial communities closely resembles that of arid to semi-arid environments with the dominant bacterial phyla in the soils being Firmicutes, Actinobacteria, Proteobacteria, Chloroflexi, Gemmatimonadetes, Acidobacteria, and Verrucomicrobia. We showed that, in the range of soil conditions created by climatic variations and soil heterogeneity, bacterial $\alpha$-diversity was stable with a similar diversity pattern, while $\beta$-diversity highlighted different bacterial community structures as a function of the pedoclimatic origin of the soil samples. Our analyses revealed that the $\beta$-diversity variations were mainly driven by a few bacterial genera. In this semi-arid environment where annual mean rainfall is a determining factor in the type of land cover, soil moisture emerged as a strong predictor, and soil $\mathrm{pH}$ as the main environmental driver affecting the composition and the spatial distribution of bacterial communities in the Sahelo-Sudanian region.

\section{Acknowledgements}

We would like to thank Dr Laetitia Bernard (Eco \& Sols), coordinator of the CAMMiSolE project. We also thank Dr Ranjard and his team at INRA UMR1347 Agroécologie, Dijon for the assistance and advices with R packages analysis. We also thank the LEMSAT Laboratory team L. Dieng, M. Gueye, M. Sané, L. Sagna, O. Faye (IRD, LMI IESOL, Senegal) for assisting with soil analyses and other laboratory work.

\section{Funding}

The present study was funded by the French Foundation for Research on Biodi- 
versity (FRB-AAP-SCEN-2013 II-CAMMiSolE project). S.B. Diatta was funded by a grant from the CAMMiSolE project.

\section{Conflicts of Interest}

The authors declare no conflict of interest.

\section{References}

[1] Torsvik, V. and Øvreås, L. (2002) Microbial Diversity and Function in Soil: From Genes to Ecosystems. Current Opinion in Microbiology, 5, 240-245. https://doi.org/10.1016/S1369-5274(02)00324-7

[2] Zhang, Y., Dong, S., Gao, Q., Liu, S., Ganjurjav, H., Wang, X., et al. (2017) Soil Bacterial and Fungal Diversity Differently Correlated with Soil Biochemistry in Alpine Grassland Ecosystems in Response to Environmental Changes. Scientific Reports, 7, Article No. 43077. https://doi.org/10.1038/srep43077

[3] Fierer, N., Leff, J.W., Adams, B.J., Nielsen, U.N., Bates, S.T., Lauber, C.L., et al. (2012) Cross-Biome Metagenomic Analyses of Soil Microbial Communities and Their Functional Attributes. Proceedings of the National Academy of Sciences of the United States of America, 109, 21390-21395. https://doi.org/10.1073/pnas.1215210110

[4] Gardi, C., Montanarella, L., Arrouays, D., Bispo, A., Lemanceau, P., Jolivet, C., et al. (2009) Soil Biodiversity Monitoring in Europe: Ongoing Activities and Challenges. European Journal of Soil Science, 60, 807-819. https://doi.org/10.1111/j.1365-2389.2009.01177.x

[5] Nielsen, U.N. and Ball, B.A. (2015) Impacts of Altered Precipitation Regimes on Soil Communities and Biogeochemistry in Arid and Semi-Arid Ecosystems. Global Change Biology, 21, 1407-1421. https://doi.org/10.1111/gcb.12789

[6] Karlson, M. and Ostwald, M. (2016) Remote Sensing of Vegetation in the Sudano-Sahelian Zone: A Literature Review from 1975 to 2014. Journal of Arid Environments, 124, 257-269. https://doi.org/10.1016/j.jaridenv.2015.08.022

[7] Alonge, C.J., Mohr, K.I., Tao, W.-K., Alonge, C.J., Mohr, K.I. and Tao, W.-K. (2007) Numerical Studies of Wet versus Dry Soil Regimes in the West African Sahel. Journal of Hydrometeorology, 8, 102-116. https://doi.org/10.1175/JHM559.1

[8] Fensholt, R., Mbow, C., Brandt, M. and Rasmussen, K. (2017) Desertification and Re-Greening of the Sahel. Oxford Research Encyclopedia of Climate Science, 1. https://doi.org/10.1093/acrefore/9780190228620.013.553

[9] Nicholson, S.E. (2013) The West African Sahel: A Review of Recent Studies on the Rainfall Regime and Its Interannual Variability. ISRN Meteorology, 2013, Article ID: 453521. https://doi.org/10.1155/2013/453521

[10] Le Houérou, H.N. (1989) Definition, Geographical Limits, Contacts with Other Ecoclimatic Zones. In: The Grazing Land Ecosystems of the African Sahel. Ecological Studies (Analysis and Synthesis), Vol. 75, Springer, Berlin, Heidelberg, 1-16. https://doi.org/10.1007/978-3-642-74457-0_1

[11] Bégué, A., Vintrou, E., Ruelland, D., Claden, M. and Dessay, N. (2011) Can a 25-Year Trend in Soudano-Sahelian Vegetation Dynamics Be Interpreted in Terms of Land Use Change? A Remote Sensing Approach. Global Environmental Change, 21, 413-420. https://doi.org/10.1016/j.gloenvcha.2011.02.002

[12] Sinare, H. and Gordon, L.J. (2015) Ecosystem Services from Woody Vegetation on 
Agricultural Lands in Sudano-Sahelian West Africa. Agriculture, Ecosystems and Environment, 200, 186-199. https://doi.org/10.1016/j.agee.2014.11.009

[13] Chappell, A. and Agnew, C.T. (2004) Modelling Climate Change in West African Sahel Rainfall (1931-90) as an Artifact of Changing Station Locations. International Journal of Climatology, 24, 547-554. https://doi.org/10.1002/joc.1021

[14] Le Barbé, L., Lebel, T. and Tapsoba, D. (2002) Rainfall Variability in West Africa during the Years 1950-90. Journal of Climate, 15, 187-202. https://doi.org/10.1175/1520-0442(2002)015<0187:RVIWAD>2.0.CO;2

[15] Nicholson, S.E. (2000) Land Surface Processes and Sahel Climate. Reviews of Geophysics, 38, 117-139. https://doi.org/10.1029/1999RG900014

[16] Nicholson, S.E. and Grist, J.P. (2003) The Seasonal Evolution of the Atmospheric Circulation over West Africa and Equatorial Africa. Journal of Climate, 16, 1013-1030. https://doi.org/10.1175/1520-0442(2003)016<1013:TSEOTA $>2.0 . C O ; 2$

[17] Rodríguez-Fonseca, B., Mohino, E., Mechoso, C.R., Caminade, C., Biasutti, M., Gaetani, M., et al. (2015) Variability and Predictability of West African Droughts: A Review on the Role of Sea Surface Temperature Anomalies. Journal of Climate, 28, 4034-4060. https://doi.org/10.1175/JCLI-D-14-00130.1

[18] Sultan, B. and Janicot, S. (2000) Abrupt Shift of the ITCZ over West Africa and Intra-Seasonal Variability. Geophysical Research Letters, 27, 3353-3356. https://doi.org/10.1029/1999GL011285

[19] Nicholson, S.E., Tucker, C.J. and Ba, M.B. (1998) Desertification, Drought, and Surface Vegetation: An Example from the West African Sahel. Bulletin of the American Meteorological Society, 79, 815-829. https://doi.org/10.1175/1520-0477(1998)079<0815:DDASVA>2.0.CO;2

[20] Xue, Y., Boone, A. and Taylor, C.M. (2012) Review of Recent Developments and the Future Prospective in West African Atmosphere/Land Interaction Studies. International Journal of Geophysics, 2012, Article ID: 748921. https://doi.org/10.1155/2012/748921

[21] Farrar, T.J., Nicholson, S.E. and Lare, A.R. (1994) The Influence of Soil Type on the Relationships between NDVI, Rainfall, and Soil Moisture in Semiarid Botswana. II. NDVI Response to Soil Oisture. Remote Sensing of Environment, 50, 121-133. https://doi.org/10.1016/0034-4257(94)90039-6

[22] Wardell, A., Reenberg, A. and Tøttrup, C. (2003) Historical Footprints in Contemporary Land Use Systems: Forest Cover Changes in Savannah Woodlands in the Sudano-Sahelian Zone. Global Environmental Change, 13, 235-254. https://doi.org/10.1016/S0959-3780(03)00056-6

[23] Herrmann, S.M. and Tappan, G.G. (2013) Vegetation Impoverishment Despite Greening: A Case Study from Central Senegal. Journal of Arid Environments, 90, 55-66. https://doi.org/10.1016/j.jaridenv.2012.10.020

[24] Mbow, C., Fensholt, R., Rasmussen, K. and Diop, D. (2013) Can Vegetation Productivity Be Derived from Greenness in a Semi-Arid Environment? Evidence from Ground-Based Measurements. Journal of Arid Environments, 97, 56-65. https://doi.org/10.1016/j.jaridenv.2013.05.011

[25] Bocksberger, G., Schnitzler, J., Chatelain, C., Daget, P., Janssen, T., Schmidt, M., et al. (2016) Climate and the Distribution of Grasses in West Africa. Journal of Vegetation Science, 27, 306-317. https://doi.org/10.1111/jvs.12360

[26] Diouf, A.A., Hiernaux, P., Brandt, M., Faye, G., Djaby, B., Diop, M.B., et al. (2016) Do Agrometeorological Data Improve Optical Satellite-Based Estimations of the Herbaceous Yield in Sahelian Semi-Arid Ecosystems? Remote Sensing, 8, 668. 
https://doi.org/10.3390/rs8080668

[27] Brandt, M., Tappan, G., Diouf, A., Beye, G., Mbow, C. and Fensholt, R. (2017) Woody Vegetation Die off and Regeneration in Response to Rainfall Variability in the West African Sahel. Remote Sensing, 9, 39. https://doi.org/10.3390/rs9010039

[28] Leroux, L., Bégué, A., Lo Seen, D., Jolivot, A. and Kayitakire, F. (2017) Driving Forces of Recent Vegetation Changes in the Sahel: Lessons Learned from Regional and Local Level Analyses. Remote Sensing of Environment, 191, 38-54. https://doi.org/10.1016/j.rse.2017.01.014

[29] Herrmann, S.M., Anyamba, A. and Tucker, C.J. (2005) Recent Trends in Vegetation Dynamics in the African Sahel and Their Relationship to Climate. Global Environmental Change, 15, 394-404. https://doi.org/10.1016/j.gloenvcha.2005.08.004

[30] Stefan, G., Cornelia, B., Jörg, R. and Michael, B. (2014) Soil Water Availability Strongly Alters the Community Composition of Soil Protists. Pedobiologia, 57, 205-213. https://doi.org/10.1016/j.pedobi.2014.10.001

[31] Zhang, X., Zhang, G., Chen, Q. and Han, X. (2013) Soil Bacterial Communities Respond to Climate Changes in a Temperate Steppe. PLOS ONE, 8, e78616.

https://doi.org/10.1371/journal.pone.0078616

[32] Hu, Y., Xiang, D., Veresoglou, S.D., Chen, F., Chen, Y., Hao, Z., et al. (2014) Soil Organic Carbon and Soil Structure Are Driving Microbial Abundance and Community Composition across the Arid and Semi-Arid Grasslands in Northern China. Soil Biology and Biochemistry, 77, 51-57. https://doi.org/10.1016/j.soilbio.2014.06.014

[33] Chu, H., Fierer, N., Lauber, C.L., Caporaso, J.G., Knight, R. and Grogan, P. (2010) Soil Bacterial Diversity in the Arctic Is Not Fundamentally Different from That Found in Other Biomes. Environmental Microbiology, 12, 2998-3006. https://doi.org/10.1111/j.1462-2920.2010.02277.x

[34] Chong, C.W., Pearce, D.A., Convey, P. and Tan, I.K.P. (2012) The Identification of Environmental Parameters Which Could Influence Soil Bacterial Community Composition on the Antarctic Peninsula-A Statistical Approach. Antarctic Science, 24, 249-258. https://doi.org/10.1017/S0954102012000028

[35] Connon, S.A., Lester, E.D., Shafaat, H.S., Obenhuber, D.C. and Ponce, A. (2007) Bacterial Diversity in Hyperarid Atacama Desert Soils. Journal of Geophysical Research: Biogeosciences, 112, G04S17. https://doi.org/10.1029/2006JG000311

[36] An, S., Couteau, C., Luo, F., Neveu, J. and DuBow, M.S. (2013) Bacterial Diversity of Surface Sand Samples from the Gobi and Taklamaken Deserts. Microbial Ecology, 66, 850-860. https://doi.org/10.1007/s00248-013-0276-2

[37] Cao, P., Wang, J.-T., Hu, H.-W., Zheng, Y.-M., Ge, Y., Shen, J.-P. and He, J.-Z. (2016) Environmental Filtering Process Has More Important Roles than Dispersal Limitation in Shaping Large-Scale Prokaryotic Beta Diversity Patterns of Grassland Soils. Microbial Ecology, 72, 221-230. https://doi.org/10.1007/s00248-016-0762-4

[38] Yao, M., Rui, J., Niu, H., Heděnec, P., Li, J., He, Z., et al. (2017) The Differentiation of Soil Bacterial Communities along a Precipitation and Temperature Gradient in the Eastern Inner Mongolia Steppe. CATENA, 152, 47-56.

https://doi.org/10.1016/j.catena.2017.01.007

[39] Brockett, B.F.T., Prescott, C.E. and Grayston, S.J. (2012) Soil Moisture Is the Major Factor Influencing Microbial Community Structure and Enzyme Activities across Seven Biogeoclimatic Zones in Western Canada. Soil Biology and Biochemistry, 44, 9-20. https://doi.org/10.1016/j.soilbio.2011.09.003 
[40] Rughöft, S., Herrmann, M., Lazar, C.S., Cesarz, S., Levick, S.R., Trumbore, S.E. and Küsel, K. (2016) Community Composition and Abundance of Bacterial, Archaeal and Nitrifying Populations in Savanna Soils on Contrasting Bedrock Material in Kruger National Park, South Africa. Frontiers in Microbiology, 7, 1638. https://doi.org/10.3389/fmicb.2016.01638

[41] Bachar, A., Al-Ashhab, A., Soares, M.I.M., Sklarz, M.Y., Angel, R., Ungar, E.D. and Gillor, O. (2010) Soil Microbial Abundance and Diversity Along a Low Precipitation Gradient. Microbial Ecology, 60, 453-461.

https://doi.org/10.1007/s00248-010-9727-1

[42] Prober, S.M., Leff, J.W., Bates, S.T., Borer, E.T., Firn, J., Harpole, W.S., et al. (2015) Plant Diversity Predicts Beta but Not Alpha Diversity of Soil Microbes across Grasslands Worldwide. Ecology Letters, 18, 85-95. https://doi.org/10.1111/ele.12381

[43] Zeng, Q., Dong, Y. and An, S. (2016) Bacterial Community Responses to Soils along a Latitudinal and Vegetation Gradient on the Loess Plateau, China. PLoS ONE, 11, e0152894. https://doi.org/10.1371/journal.pone.0152894

[44] Acosta-Martínez, V., Dowd, S., Sun, Y. and Allen, V. (2008) Tag-Encoded Pyrosequencing Analysis of Bacterial Diversity in a Single Soil Type as Affected by Management and Land Use. Soil Biology and Biochemistry, 40, 2762-2770.

https://doi.org/10.1016/j.soilbio.2008.07.022

[45] Lauber, C.L., Hamady, M., Knight, R. and Fierer, N. (2009) Pyrosequencing-Based Assessment of Soil $\mathrm{pH}$ as a Predictor of Soil Bacterial Community Structure at the continental Scale. Applied and Environmental Microbiology, 75, 5111-5120. https://doi.org/10.1128/AEM.00335-09

[46] Kim, M., Boldgiv, B., Singh, D., Chun, J., Lkhagva, A. and Adams, J.M. (2013) Structure of Soil Bacterial Communities in Relation to Environmental Variables in a Semi-Arid Region of Mongolia. Journal of Arid Environments, 89, 38-44. https://doi.org/10.1016/j.jaridenv.2012.09.014

[47] Fierer, N., Schimel, J.P. and Holden, P.A. (2003) Variations in Microbial Community Composition through Two Soil Depth Profiles. Soil Biology and Biochemistry, 35, 167-176. https://doi.org/10.1016/S0038-0717(02)00251-1

[48] Li, Y., Adams, J., Shi, Y., Wang, H., He, J.-S. and Chu, H. (2017) Distinct Soil Microbial Communities in Habitats of Differing Soil Water Balance on the Tibetan Plateau. Scientific Reports, 7, Article No. 46407. https://doi.org/10.1038/srep46407

[49] Xue, P.-P., Carrillo, Y., Pino, V., Minasny, B. and McBratney, A.B. (2018) Soil Properties Drive Microbial Community Structure in a Large Scale Transect in South Eastern Australia. Scientific Reports, 8, Article No. 11725. https://doi.org/10.1038/s41598-018-30005-8

[50] Griffiths, R.I., Thomson, B.C., James, P., Bell, T., Bailey, M. and Whiteley, A.S. (2011) The Bacterial Biogeography of British Soils. Environmental Microbiology, 13, 1642-1654. https://doi.org/10.1111/j.1462-2920.2011.02480.x

[51] Gritzner J.H. (2005) Senegal. Philadelphia: Chelsea House Publisher.

[52] Fall, S., Semazzi, F.H.M., Niyogi, D.D.S., Anyah, R.O. and Bowden, J. (2006) The Spatiotemporal Climate Variability over Senegal and Its Relationship to Global Climate. International Journal of Climatology, 26, 2057-2076. https://doi.org/10.1002/joc.1355

[53] Tappan, G., Sall, M., Wood, E. and Cushing, M. (2004) Ecoregions and Land Cover Trends in Senegal. Journal of Arid Environments, 59, 427-462. https://doi.org/10.1016/j.jaridenv.2004.03.018 
[54] Fick, S.E. and Hijmans, R.J. (2017) WorldClim 2: New 1-km Spatial Resolution Climate Surfaces for Global Land Areas. International Journal of Climatology, 37, 4302-4315. https://doi.org/10.1002/joc.5086

[55] Aubert, G., Ollat, C. and Pinta, M. (1954) Méthodes d'analyses utilisées actuellement aux laboratoires des sols de l'IDERT. http://www.documentation.ird.fr/hor/fdi:11213

[56] Caporaso, J.G., Lauber, C.L., Walters, W.A., Berg-Lyons, D., Lozupone, C.A., Turnbaugh, P.J., et al. (2011) Global Patterns of 16S rRNA Diversity at a Depth of Millions of Sequences per Sample. Proceedings of the National Academy of Sciences of the United States of America, 108, 4516-4522. https://doi.org/10.1073/pnas.1000080107

[57] DeSantis, T.Z., Hugenholtz, P., Larsen, N., Rojas, M., Brodie, E.L., Keller, K., et al. (2006) Greengenes, a Chimera-Checked 16S rRNA Gene Database and Workbench Compatible with ARB. Applied and Environmental Microbiology, 72, 5069-5072. https://doi.org/10.1128/AEM.03006-05

[58] R Core Team (2018) R: A Language and Environment for Statistical Computing. R Foundation for Statistical Computing, Vienna, Austria. https://www.r-project.org/

[59] McMurdie, P.J. and Holmes, S. (2013) Phyloseq: An R Package for Reproducible Interactive Analysis and Graphics of Microbiome Census Data. PLoS ONE, 8, e61217. https://doi.org/10.1371/journal.pone.0061217

[60] Addinsoft (2016) XLSTAT 2016: Data Analysis and Statistical Solution for Microsoft Excel. https://www.xlstat.com/fr/

[61] Oksanen, J., Blanchet, F.G., Friendly, M., Kindt, R., Legendre, P., McGlinn, D., et al. (2018) Vegan: Community Ecology Package.

https://cran.r-project.org/web/packages/vegan/index.html

[62] Rohart, F., Gautier, B., Singh, A. and Lê Cao, K.A. (2017) mixOmics: An R Package for 'Omics Feature Selection and Multiple Data Integration. PLoS Computational Biology, 13, e1005752. https://doi.org/10.1371/journal.pcbi.1005752

[63] Liquet, B., Cao, K.-A.L., Hocini, H. and Thiébaut, R. (2012) A Novel Approach for Biomarker Selection and the Integration of Repeated Measures Experiments from Two Assays. BMC Bioinformatics, 13, 325. https://doi.org/10.1186/1471-2105-13-325

[64] Janssen, P.H. (2006) Identifying the Dominant Soil Bacterial Taxa in Libraries of 16S rRNA and 16S rRNA Genes. Applied and Environmental Microbiology, 72, 1719-1728. https://doi.org/10.1128/AEM.72.3.1719-1728.2006

[65] Ronca, S., Ramond, J.-B., Jones, B.E., Seely, M. and Cowan, D.A. (2015) Namib Desert Dune/Interdune Transects Exhibit Habitat-Specific Edaphic Bacterial Communities. Frontiers in Microbiology, 6, 845. https://doi.org/10.3389/fmicb.2015.00845

[66] Shi, P., Zhang, Y., Hu, Z., Ma, K., Wang, H. and Chai, T. (2017) The Response of Soil Bacterial Communities to Mining Subsidence in the West China Aeolian Sand Area. Applied Soil Ecology, 121, 1-10. https://doi.org/10.1016/j.apsoil.2017.09.020

[67] Köberl, M., Müller, H., Ramadan, E.M. and Berg, G. (2011) Desert Farming Benefits from Microbial Potential in Arid Soils and Promotes Diversity and Plant Health. PLoS ONE, 6, e24452. https://doi.org/10.1371/journal.pone.0024452

[68] Bainard, L.D., Hamel, C. and Gan, Y. (2016) Edaphic Properties Override the Influence of Crops on the Composition of the Soil Bacterial Community in a Semiarid Agroecosystem. Applied Soil Ecology, 105, 160-168. 
https://doi.org/10.1016/j.apsoil.2016.03.013

[69] Zhang, L., Xie, Z., Zhao, R. and Zhang, Y. (2018) Plant, Microbial Community and Soil Property Responses to an Experimental Precipitation Gradient in a Desert Grassland. Applied Soil Ecology, 127, 87-95. https://doi.org/10.1016/j.apsoil.2018.02.005

[70] Grist, J.P. and Nicholson, S.E. (2001) A Study of the Dynamic Factors Influencing the Rainfall Variability in the West African Sahel. Journal of Climate, 14, 1337-1359. https://doi.org/10.1175/1520-0442(2001)014<1337:ASOTDF>2.0.CO;2

[71] Hulme, M. (2001) Climatic Perspectives on Sahelian Desiccation: 1973-1998. Global Environmental Change, 11, 19-29. https://doi.org/10.1016/S0959-3780(00)00042-X

[72] Hänke, H., Börjeson, L., Hylander, K. and Enfors-Kautsky, E. (2016) Drought Tolerant Species Dominate as Rainfall and Tree Cover Returns in the West African Sahel. Land Use Policy, 59, 111-120. https://doi.org/10.1016/j.landusepol.2016.08.023

[73] Lebel, T. and Ali, A. (2009) Recent Trends in the Central and Western Sahel Rainfall Regime (1990-2007). Journal of Hydrology, 375, 52-64.

https://doi.org/10.1016/j.jhydrol.2008.11.030

[74] Evans, S.E. and Wallenstein, M.D. (2012) Soil Microbial Community Response to Drying and Rewetting Stress: Does Historical Precipitation Regime Matter? Biogeochemistry, 109, 101-116. https://doi.org/10.1007/s10533-011-9638-3

[75] Barnard, R.L., Osborne, C.A. and Firestone, M.K. (2013) Responses of Soil Bacterial and Fungal Communities to Extreme Desiccation and Rewetting. The ISME Journal, 7, 2229-2241. https://doi.org/10.1038/ismej.2013.104

[76] Makhalanyane, T.P., Valverde, A., Gunnigle, E., Frossard, A., Ramond, J.-B. and Cowan, D.A. (2015) Microbial Ecology of Hot Desert Edaphic Systems. FEMS Microbiology Reviews, 39, 203-221. https://doi.org/10.1093/femsre/fuu011

[77] DeBruyn, J.M., Nixon, L.T., Fawaz, M.N., Johnson, A.M. and Radosevich, M. (2011) Global Biogeography and Quantitative Seasonal Dynamics of Gemmatimonadetes in Soil. Applied and Environmental Microbiology, 77, 6295-6300. https://doi.org/10.1128/AEM.05005-11

[78] Fierer, N., Bradford, M.A. and Jackson, R.B. (2007) Toward an Ecological Classification of Soil Bacteria. Ecology, 88, 1354-1364. https://doi.org/10.1890/05-1839

[79] Kielak, A.M., Barreto, C.C., Kowalchuk, G.A., van Veen, J.A. and Kuramae, E.E. (2016) The Ecology of Acidobacteria: Moving beyond Genes and Genomes. Frontiers in Microbiology, 7, 744. https://doi.org/10.3389/fmicb.2016.00744

[80] CCregger, M.A., Schadt, C.W., McDowell, N.G., Pockman, W.T. and Classen, A.T. (2012) Response of the Soil Microbial Community to Changes in Precipitation in a Semiarid Ecosystem. Applied and Environmental Microbiology, 78, 8587-8594. https://doi.org/10.1128/AEM.02050-12

[81] Si, G., Lei, T., Xia, Y., Yuan, Y. and Zhang, G. (2016) Microbial Nonlinear Response to a Precipitation Gradient in the Northeastern Tibetan Plateau. Geomicrobiology Journal, 33, 85-97. https://doi.org/10.1080/01490451.2014.1001094

[82] Evans, S.E. and Wallenstein, M.D. (2014) Climate Change Alters Ecological Strategies of Soil Bacteria. Ecology Letters, 17, 155-164. https://doi.org/10.1111/ele.12206

[83] Philippot, L., Bru, D., Saby, N.P.A., Čuhel, J., Arrouays, D., Šimek, M. and Hallin, S. (2009) Spatial Patterns of Bacterial Taxa in Nature Reflect Ecological Traits of Deep Branches of the 16S rRNA Bacterial Tree. Environmental Microbiology, 11, 3096-3104. https://doi.org/10.1111/j.1462-2920.2009.02014.x

[84] Philippot, L., Andersson, S.G.E., Battin, T.J., Prosser, J.I., Schimel, J.P., Whitman, 
W.B. and Hallin, S. (2010) The Ecological Coherence of High Bacterial Taxonomic Ranks. Nature Reviews Microbiology, 8, 523-529. https://doi.org/10.1038/nrmicro2367

[85] Hartmann, M. and Widmer, F. (2006) Community Structure Analyses Are More Sensitive to Differences in Soil Bacterial Communities than Anonymous Diversity Indices. Applied and Environmental Microbiology, 72, 7804-7812. https://doi.org/10.1128/AEM.01464-06

[86] Angel, R., Soares, M.I.M., Ungar, E.D. and Gillor, O. (2010) Biogeography of Soil Archaea and Bacteria along a Steep Precipitation Gradient. The ISME Journal, 4, 553-563. https://doi.org/10.1038/ismej.2009.136

[87] Van Horn, D.J., Van Horn, M.L., Barrett, J.E., Gooseff, M.N., Altrichter, A.E., Geyer, K.M., et al. (2013) Factors Controlling Soil Microbial Biomass and Bacterial Diversity and Community Composition in a Cold Desert Ecosystem: Role of Geographic Scale. PLoS ONE, 8, e66103. https://doi.org/10.1371/journal.pone.0066103

[88] Xiong, J., Liu, Y., Lin, X., Zhang, H., Zeng, J., Hou, J., et al. (2012) Geographic Distance and $\mathrm{pH}$ Drive Bacterial Distribution in Alkaline Lake Sediments across Tibetan Plateau. Environmental Microbiology, 14, 2457-2466.

https://doi.org/10.1111/j.1462-2920.2012.02799.x

[89] Fierer, N. and Jackson, R.B. (2006) The Diversity and Biogeography of Soil Bacterial Communities. Proceedings of the National Academy of Sciences of the United States of America, 103, 626-631. https://doi.org/10.1073/pnas.0507535103

[90] Shen, C., Xiong, J., Zhang, H., Feng, Y., Lin, X., Li, X., et al. (2013) Soil pH Drives the Spatial Distribution of Bacterial Communities along Elevation on Changbai Mountain. Soil Biology and Biochemistry, 57, 204-211. https://doi.org/10.1016/j.soilbio.2012.07.013

[91] Xia, Z., Bai, E., Wang, Q., Gao, D., Zhou, J., Jiang, P. and Wu, J. (2016) Biogeographic Distribution Patterns of Bacteria in Typical Chinese Forest Soils. Frontiers in Microbiology, 7, 1106. https://doi.org/10.3389/fmicb.2016.01106

[92] Andrew, D.R., Fitak, R.R., Munguia-Vega, A., Racolta, A., Martinson, V.G. and Dontsova, K. (2012) Abiotic Factors Shape Microbial Diversity in Sonoran Desert Soils. Applied and Environmental Microbiology, 78, 7527-7537. https://doi.org/10.1128/AEM.01459-12

[93] Peralta, R.M., Ahn, C. and Gillevet, P.M. (2013) Characterization of Soil Bacterial Community Structure and Physicochemical Properties in Created and Natural Wetlands. Science of The Total Environment, 443, 725-732. https://doi.org/10.1016/j.scitotenv.2012.11.052

[94] Tripathi, B.M., Kim, M., Singh, D., Lee-Cruz, L., Lai-Hoe, A., Ainuddin, A.N., et al. (2012) Tropical Soil Bacterial Communities in Malaysia: $\mathrm{pH}$ Dominates in the Equatorial Tropics Too. Microbial Ecology, 64, 474-484. https://doi.org/10.1007/s00248-012-0028-8

[95] Rousk, J., Bååth, E., Brookes, P.C., Lauber, C.L., Lozupone, C., Caporaso, J.G., et al. (2010) Soil Bacterial and Fungal Communities across a pH Gradient in an Arable Soil. The ISME Journal, 4, 1340-1351. https://doi.org/10.1038/ismej.2010.58

[96] Jones, A.R. and Brunsell, N.A. (2009) A Scaling Analysis of Soil Moisture-Precipitation Interactions in a Regional Climate Model. Theoretical and Applied Climatology, 98, 221-235. https://doi.org/10.1007/s00704-009-0109-x

[97] Blanchard, E., Albrecht, A., Bernoux, M., Brauman, A., Chotte, J.-L., Feller, C., et al. (2005) Organic Matter and Biofunctioning in Tropical Sandy Soils and Implications for Their Management. 1 st International Symposium on the Management of Trop- 
ical Sandy Soils for Sustainable Agriculture: A Holistic Approach for Sustainable Development of Problem Soils in the Tropics, Khon Kaen, Thailand, 28 November-2 December 2005. http://agritrop.cirad.fr/531834/

[98] Bruand, A., Hartmann, C. and Lesturgez, G. (2005) Physical Properties of Tropical Sandy Soils: A Large Range of Behaviours. In: Management of Tropical Sandy Soils for Sustainable Agriculture: A Holistic Approach for Sustainable Development of Problem Soils in the Tropics, FAO, Bangkok, 148-158.

http://www.documentation.ird.fr/hor/PAR00007514

[99] Faye, G., Frison, P.-L., Diouf, A.-A., Wade, S., Kane, C.A., Fussi, F., et al. (2018) Soil Moisture Estimation in Ferlo Region (Senegal) Using Radar (ENVISAT/ASAR) and Optical (SPOT/VEGETATION) Data. The Egyptian Journal of Remote Sensing and Space Science, 21, S13-S22. https://doi.org/10.1016/j.ejrs.2017.11.005

[100] Lauber, C.L., Strickland, M.S., Bradford, M.A. and Fierer, N. (2008) The Influence of Soil Properties on the Structure of Bacterial and Fungal Communities across Land-Use Types. Soil Biology and Biochemistry, 40, 2407-2415.

https://doi.org/10.1016/j.soilbio.2008.05.021

[101] Hemkemeyer, M., Dohrmann, A.B., Christensen, B.T. and Tebbe, C.C. (2018) Bacterial Preferences for Specific Soil Particle Size Fractions Revealed by Community Analyses. Frontiers in Microbiology, 9, 149.

https://doi.org/10.3389/fmicb.2018.00149

[102] Kuramae, E.E., Yergeau, E., Wong, L.C., Pijl, A.S., Veen, J.A. and Kowalchuk, G.A. (2012) Soil Characteristics More Strongly Influence Soil Bacterial Communities than Land-Use Type. FEMS Microbiology Ecology, 79, 12-24. https://doi.org/10.1111/j.1574-6941.2011.01192.x

[103] Zhou, J., Xia, B., Huang, H., Palumbo, A.V. and Tiedje, J.M. (2004) Microbial Diversity and Heterogeneity in Sandy Subsurface Soils. Applied and Environmental Microbiology, 70, 1723-1734. https://doi.org/10.1128/AEM.70.3.1723-1734.2004 


\section{Supplementary Data}

Table S1. Ecological characteristics and sampling details of the sites.

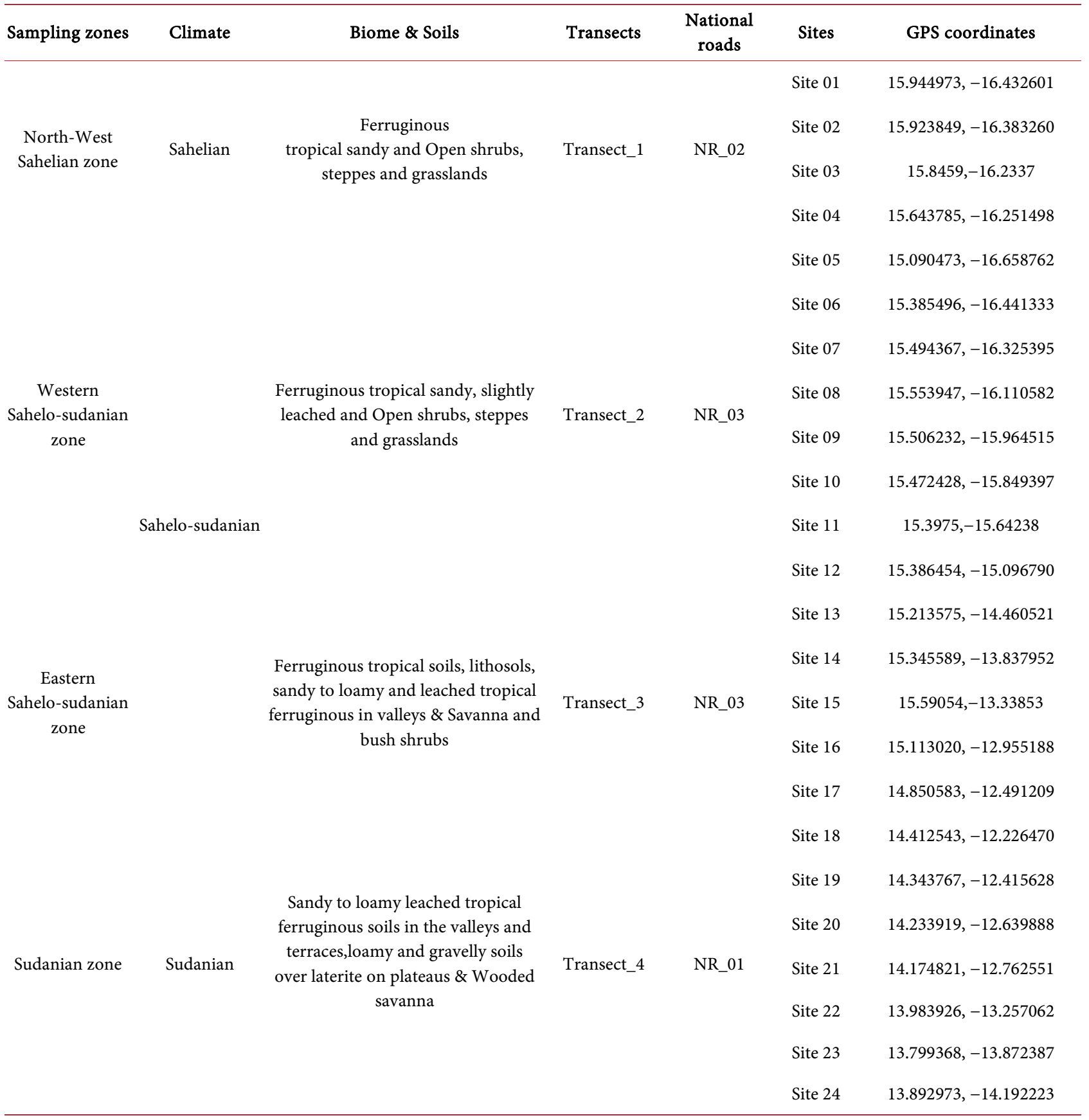

Table S2. 16S rRNA sequencing results. Number of OTUs and bacterial sequences by community fraction.

\begin{tabular}{ccc}
\hline Bacterial community fraction & Number of bacterial sequences (\%) & Number of OTUs (\%) \\
\hline All & 619.200 & 17.253 \\
Abundant $(>0.01 \%)$ & $424.031(68 \%)$ & $15.315(89 \%)$ \\
Rare $(<0.01 \%)$ & $195.169(32 \%)$ & $11 \%)$ \\
\hline
\end{tabular}


Table S3. Details of the Redundancy analysis (RDA) on the structure of the bacterial communities (Bray-Curtis dissimilarities) vs the environmental variables.

\begin{tabular}{|c|c|c|c|}
\hline Bray-Curtis distance (variance) & Inertia & Proportions & Proportions (\%) \\
\hline Total variance & 7.41 & 1 & 100 \\
\hline Constrained or explained variance & 1.78 & 0.2402 & 24 \\
\hline Unconstrained or unexplained variance & 5.63 & 0.7598 & 76 \\
\hline \multicolumn{4}{|c|}{ Contribution of the RDA components to the total variance } \\
\hline & RDA 1 & RDA 2 & RDA 3 \\
\hline Eigenvalue & 0.874 & 0.514 & 0.393 \\
\hline Proportions & 0.118 & 0.069 & 0.053 \\
\hline Proportions (\%) & 11.79 & 6.93 & 5.30 \\
\hline Cumulative proportion (\%) & 11.79 & 18.72 & 24.02 \\
\hline \multicolumn{4}{|c|}{ Contribution of the RDA components to the constrained variance } \\
\hline & RDA 1 & RDA 2 & RDA 3 \\
\hline Eigenvalue & 0.874 & 0.514 & 0.393 \\
\hline Proportions & 0.49 & 0.29 & 0.22 \\
\hline Proportions (\%) & 49.10 & 28.85 & 22.06 \\
\hline Cumulative proportion (\%) & 49.10 & 77.94 & 100.00 \\
\hline
\end{tabular}

Permutation test for the evaluation of the overall significance of the fitted model.

\begin{tabular}{cccccc}
\hline & Df & SumOfSqs & F & Pr $(>$ F $)$ & Signif \\
\hline Model & 3 & 1.780 & 2.108 & 0.001 & $* * *$ \\
Residual & 20 & 5.630 & & & \\
\hline
\end{tabular}

Permutation test for the evaluation of the individual terms of the model retained by forward selection.

\begin{tabular}{cccccc}
\hline Terms of the model & Df & SumOfSqs & F & Pr $(>$ F $)$ & 0.001 \\
\hline pH & 1 & 0.806 & 2.862 & 0.005 & Signif \\
Soil_Moisture & 1 & 0.491 & 1.743 & 0.047 & $* *$ \\
Clay & 1 & 0.394 & & & $*$ \\
Residual & 20 & 5.630 & & \\
\hline
\end{tabular}

Biplot scores of explanatory variables on RDA axis.

\begin{tabular}{cccc}
\hline Variables & RDA 1 & RDA 2 & RDA 3 \\
\hline pH & -0.999 & -0.003 & -0.044 \\
Soil_Moisture & 0.419 & 0.907 & -0.050 \\
Clay & 0.283 & 0.414 & 0.865 \\
\hline
\end{tabular}




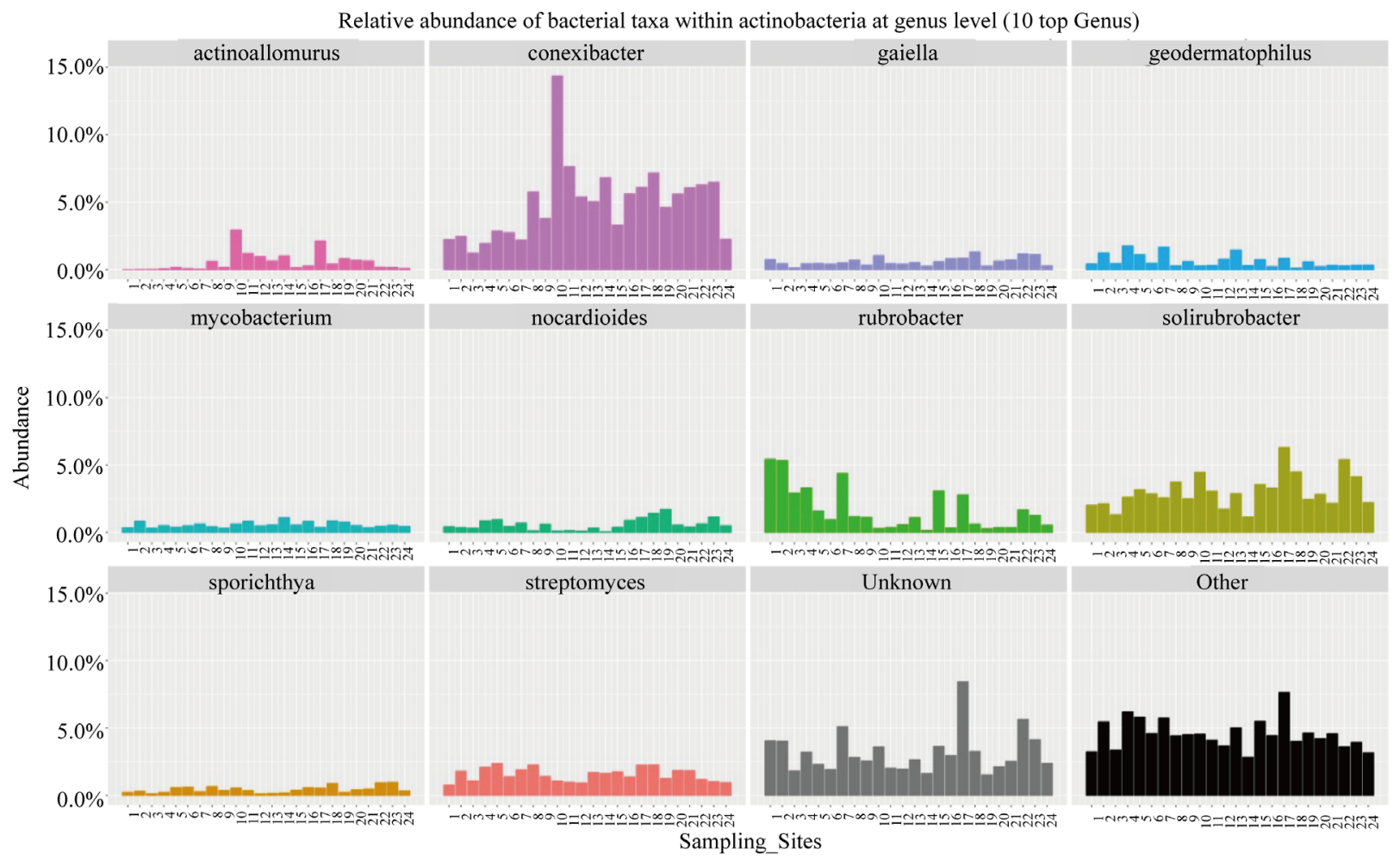

Supplementary Figure 1. Spatial distribution of relative abundance of top 10 bacterial taxa within Actinobacteria class at the genus level along the pedo-climatic gradient. 1 to 4: Sahelian-sandy zone; 5 to 13: Sahelo-sudanian sandy zone; 14 to 18 : Sahelo-sudanian loamy-sand zone; 19 to 25: Sudanian sandy-loam zone. Bacterial abundances are colored according to bacterial genera.

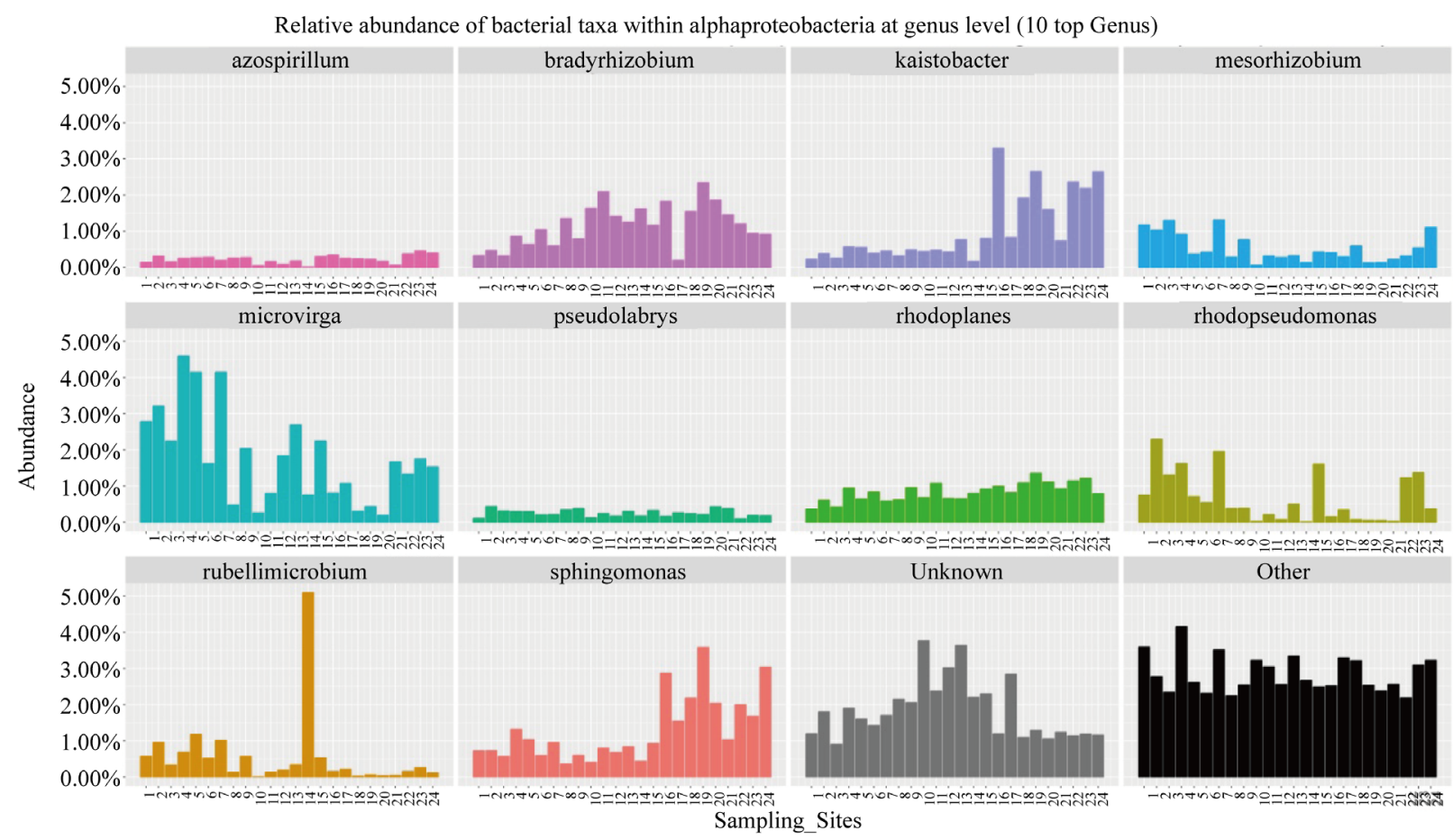

Supplementary Figure 2. Spatial distribution of relative abundance of top 10 bacterial taxa within $\alpha$-proteobacteria class at the genus level along the pedo-climatic gradient. 1 to 4: Sahelian-sandy zone; 5 to 13: Sahelo-sudanian sandy zone; 14 to 18 : Sahelo-sudanian loamy-sand zone; 19 to 25: Sudanian sandy-loam zone. Bacterial abundances are colored according to bacterial genera. 


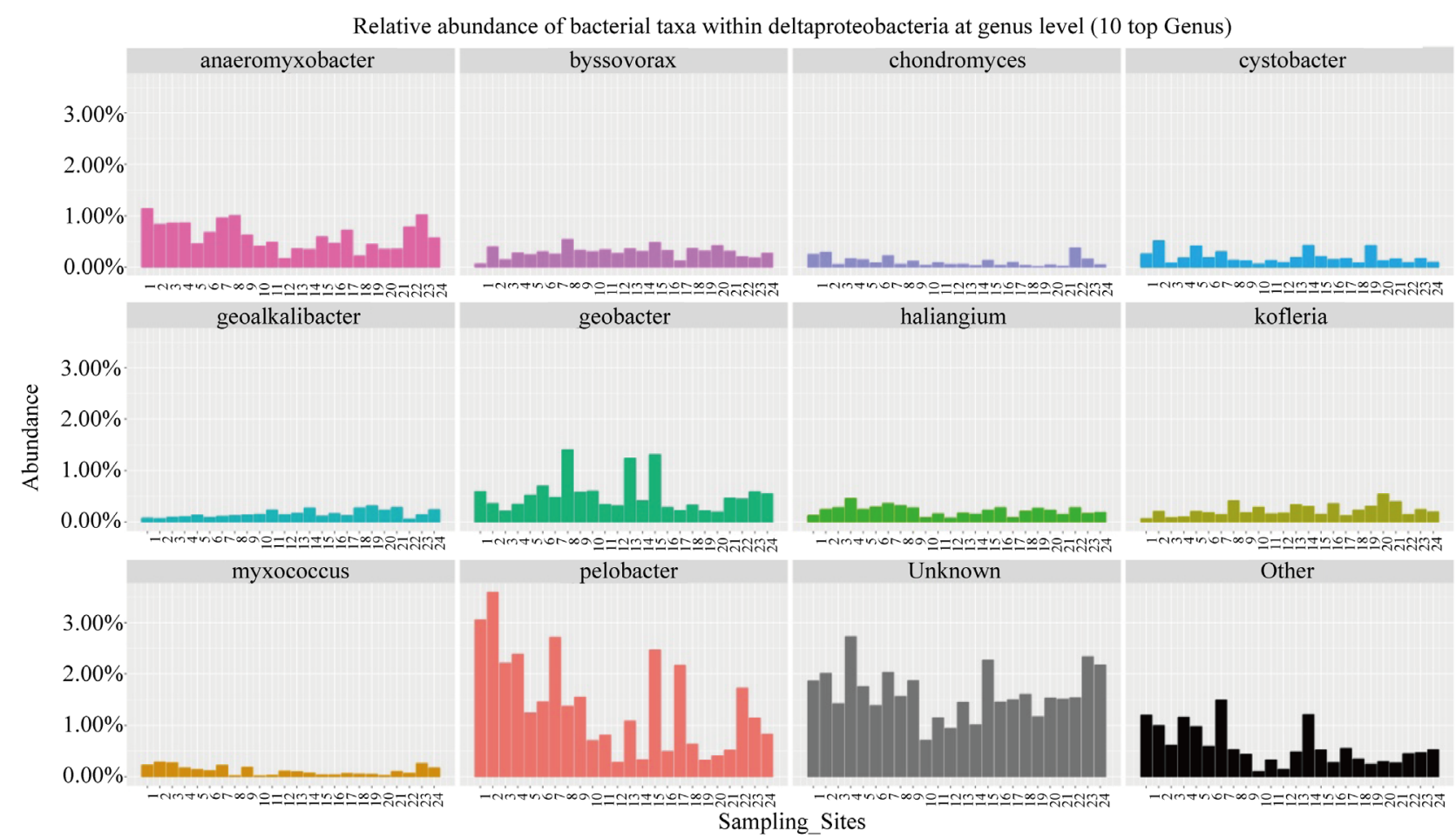

Supplementary Figure 3. Spatial distribution of relative abundance of top 10 bacterial taxa within Deltaproteobacteria class at the genus level along the pedo-climatic gradient. 1 to 4 : Sahelian-sandy zone; 5 to 13: Sahelo-sudanian sandy zone; 14 to 18 : Sahelo-sudanian loamy-sand zone; 19 to 25: Sudanian sandy-loam zone. Bacterial abundances are colored according to bacterial genera.

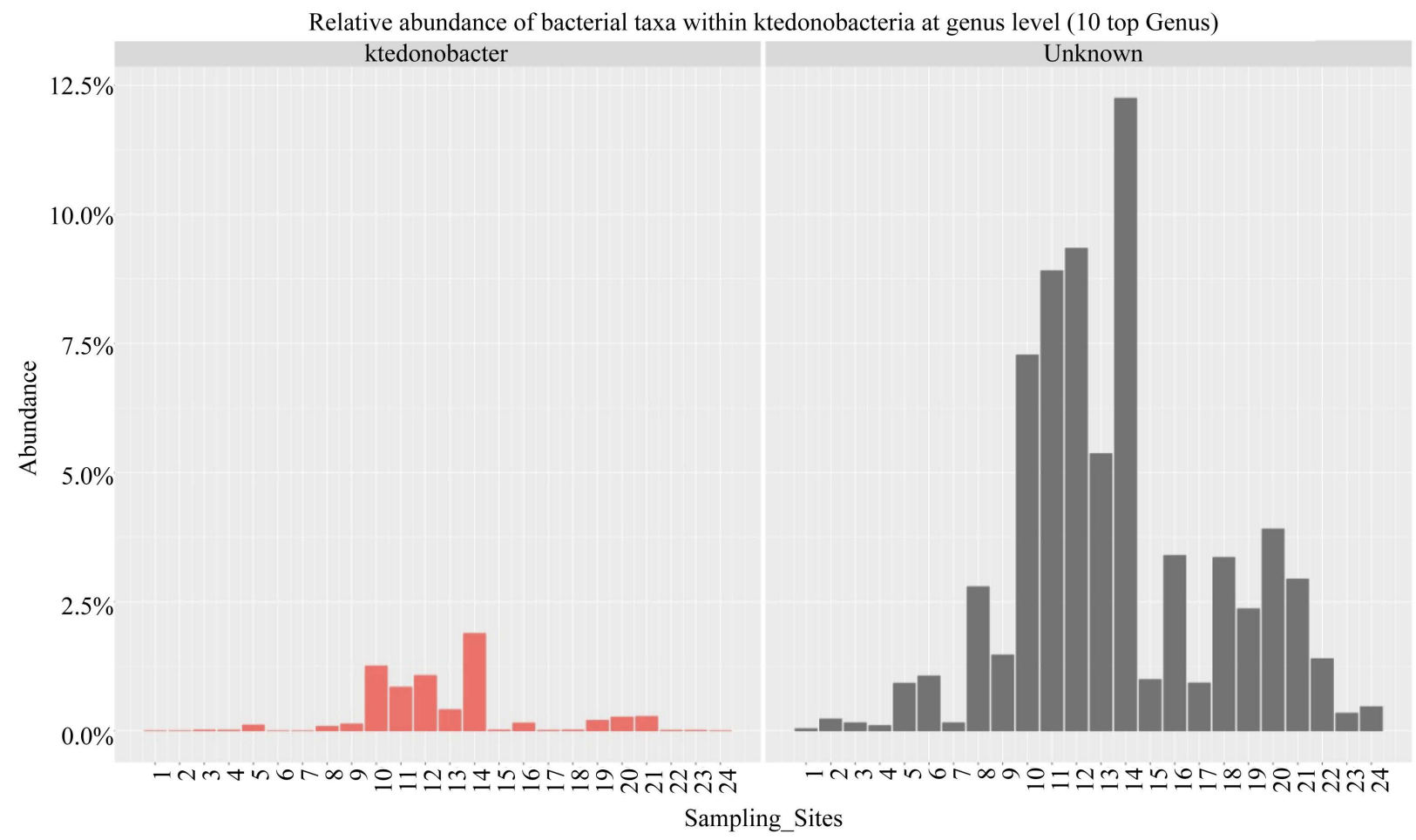

Supplementary Figure 4. Spatial distribution of relative abundance of top 10 bacterial taxa within Ktedonobacteria class at the genus level along the pedo-climatic gradient. 1 to 4 : Sahelian-sandy zone; 5 to 13: Sahelo-sudanian sandy zone; 14 to 18 : Sahelo-sudanian loamy-sand zone; 19 to 25: Sudanian sandy-loam zone. Bacterial abundances are colored according to bacterial genera. 


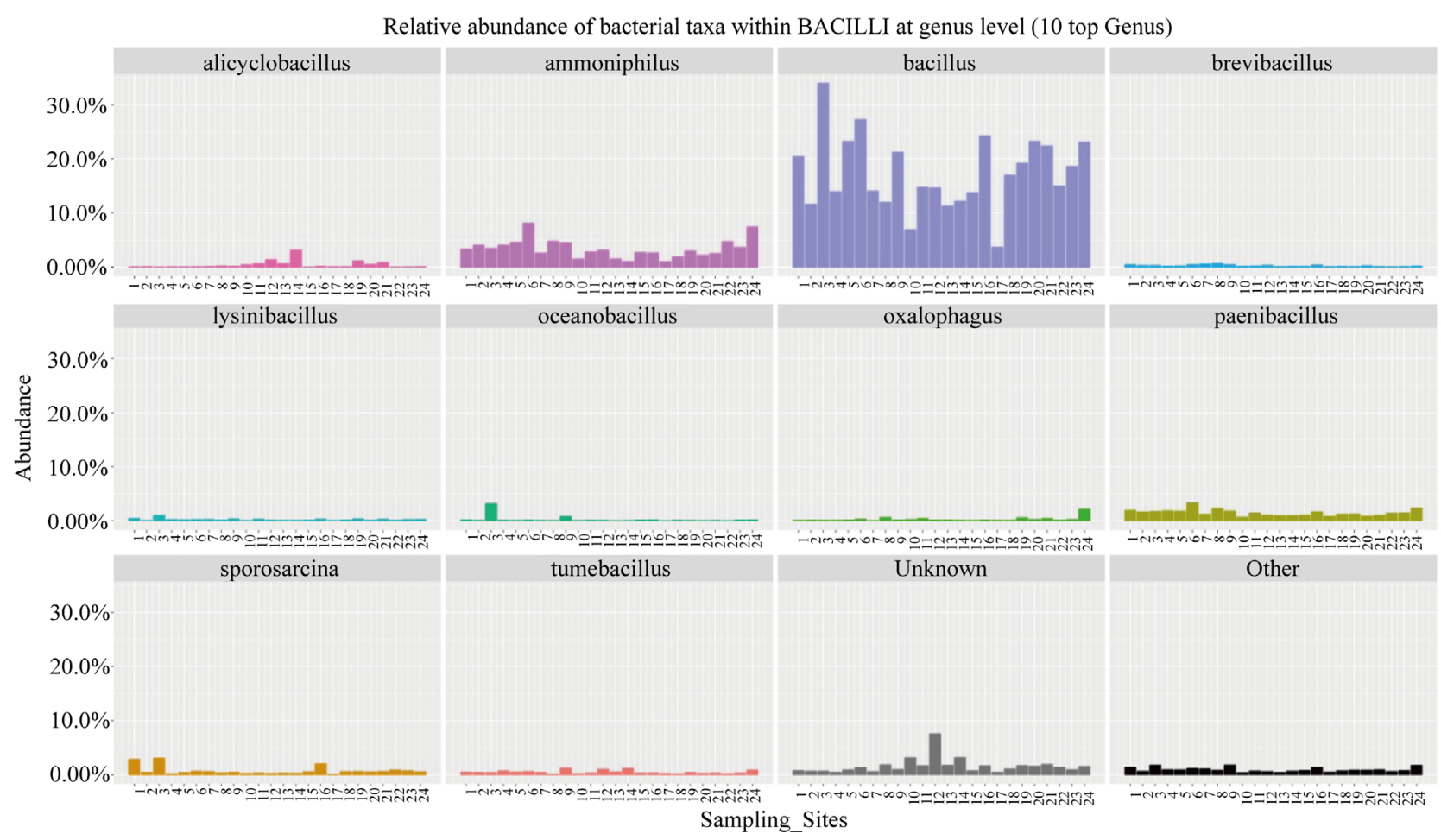

Supplementary Figure 5. Spatial distribution of relative abundance of top 10 bacterial taxa within Bacilli class at the genus level along the pedo-climatic gradient. 1 to 4: Sahelian-sandy zone; 5 to 13: Sahelo-sudanian sandy zone; 14 to 18: Sahelo-sudanian loamy-sand zone; 19 to 25: Sudanian sandy-loam zone. Bacterial abundances are colored according to bacterial genera. 